\title{
El virrey Abascal, los señores de tierras y los bandoleros en Piura Anotaciones preliminares sobre la experiencia social y política de José Sapata (a) Palomo (1814-1817)
}

\begin{abstract}
RESUMEN
Nuestra investigación busca rastrear las huellas de toda una cultura afrodescendiente de resistencia en el campesinado y de la gente de la ciudad contra otra fuerza social representado por los hacendados como don Francisco Xavier Fernández de Paredes en el valle de La Chira, Querecotillo, provincia de Piura. La documentación judicial de archivo nos permite ahora introducirnos al mundo social rural para conocer los abismos existentes entre el derecho indiano y la práctica social, el mundo social asimétrico y la reproducción de un modelo colonial ilegal en las regiones y provincias para conocer la naturaleza de las acciones de protesta colectiva que transitaban de explosiones de odio campesino hacia movimientos sangrientos que rompían la paz social y de vida de seńores y de campesinos labradores de la tierra y ganaderos cotidianos. Examina los acontecimientos de una coyuntura política de crisis regional entre los ańos de 1814-1817. Es un tiempo social en la que el subdelegado y los alcaldes de SM de Piura han podido percatarse del funcionamiento de dos movimientos sociales todavía no articulados; el primero es el de los cimarrones salteadores y de otro lado, la cuadrilla de José Sapata (a) Palomo, acusado de bandolero que ha recorrido ciudades como Lima y Piura. Esta investigación utiliza los fondos documentales guardados en los archivos judiciales regionales de Piura y Lima.
\end{abstract}

Palabras clave: bandoleros; campesinos; Piura; hacendados; Querecotillo

\section{Viceroy Abascal, Landlords and Piura bandits. Preliminary notes on social and political experience of José Sapata (a) Palomo (1814-1817)}

\begin{abstract}
Our research aims to trace afro-descendant resistance culture in peasant and urban people against another social force represented by landlords like Francisco Xavier Fernández de Paredes in La Chira Valley, Querecotillo, Piura. Archival judicial documentation from Piura and Lima introduced us to a rural social world with gaps and asymmetries between Indian law and social practice, while recurrence of an illegal colonial model in regions and provinces allowed us to acquaint the nature of collective protest actions, from peasant mobilizations of hatred to bloody movements that broke social peace of landlords, peasants, and cattlemen. We examined 1814-1817 events, a political situation of regional crisis. In this social time, subdelegate and mayors of San Miguel de Piura were able to see two social movements functioning but still not in an articulated manner; the first was the "savage» cimarrones and, the second was the gang of José Sapata (a) Palomo, accused of being a bandit who has traveled through cities such as Lima and Piura.
\end{abstract}

KEYworDs: bandits; peasants; landlords; Piura; Querecotillo

\footnotetext{
* Este artículo forma parte de un informe de investigación financiado por el Vicerrectorado de Investigación y Posgrado de la UNMSM, Código E18152021. El proyecto se titula «Transitando entre la incertidumbre y la libertad en tiempos de los Borbones y la República. Bandolerismo y negros esclavos en Piura: 1780-1821».
} 
Conflictos rurales, bandoleros y Eric Hobsbawm ${ }^{1}$

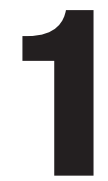

Los estudios sobre el bandolerismo formaron parte de la sociología histórica y de la historia social en los años 70 influidos por los libros de Eric Hobsbawm. En estos ańos de nacimiento y difusión del maoísmo empezaron a resaltarse a ciertas figuras históricas como a Tupac Amaru, Atusparia o José Santos Atahualpa para examinar el conflicto social en el mundo rural andino. En esta dinámica de desarrollo de las ciencias sociales ingresa el tema y estudio de los negros esclavos, los palenques, los cimarrones y el bandolerismo rural. En esta dirección destacaron los trabajos de Javier Tord Nicolini, Fernando Romero, Christina Hunefeldt, Victoria Espinosa y Wilfredo Kapsoli. ${ }^{2}$

Transcurrido casi medio siglo, encontramos que la producción historiográfica se ha incrementado en volumen y contenido. En este tiempo se ha transitado de una historia cronológica y evolucionista a una revisión crítica de los estereotipos, imágenes y construcciones históricas sobre la situación del negro esclavo y del negro liberto. Sin embargo, lo que se abandonó fue el examen del bandolerismo en sus múltiples expresiones pues se había privilegiado el análisis de su comportamiento como expresión de rebeldía y de resistencia social (José Ragas 2003 y John Dawe 1994).

Maribel Arrelucea (2018) ha publicado su libro concentrando una serie de ensayos y los resultados logrados en sus tesis de licenciatura y de magister para explorar el estudio de la población negra en la

1 Lo expuesto es un resumen apretado del texto de Bascuñan Añover, Oscar y Jesús-Carlos Urda Lozano. 2016. «El lugar del bandolero en el conflicto rural. Una aproximación historiográfica desde la obra de Eric Hobsbawm». En: Vinculos de Historia, N 5, pp.15-26. Universidad de Castilla-La Mancha, España. También puede consultarse: Rafart, Gabriel.2011. Violência rural e bandoleirismo na Patagônia. En: Topoi, N²2, pp. 118-136. UPG Historia Social, UFRJ, Brasil. Piqueras, José Antonio. 2016. La era de Hobsbawm en historia social. El Colegio de México, México. O’Phelan, Scarlett. 2018. Recuerdos sobre Eric Hobsbawm. En Serie Conferencias: 17; pp. 7 - 14. Universidad del Pacífico, Lima.

2 Sobre la historiografía acerca de esclavos y esclavitud en el Perú puede consultarse: Ragas Rojas, José. 2003. Afroperuanos: un acercamiento bibliográfico. En: Etnicidad y discriminación racial en la historia del Perú. Tomo II; pp. 190-226. Instituto Riva Agüero y Banco Mundial, Perú. Arrelucea Barrantes, Maribel. 2018. Sobreviviendo a la esclavitud. Negociación y honor en las practicas cotidianas de los africanos y afrodescendientes. Lima 1750-1820. IEP, Lima, Perú. Kapsoli, Wilfredo. 2014. Esclavitud en el Perú. En: Tradición, $\mathrm{N}^{\circ} \mid 4$, pp. 63-70. Universidad Ricardo Palma. provincia de Lima, analizando sus comportamientos, estrategias delictivas, actitudes frente a la autoridad y sus relaciones sociales cotidianas con otras castas sociales.

Esta vez se busca presentar una actualización del debate en la historiografía limeña y nacional para esbozar una serie de ideas y líneas de investigación y comprender la naturaleza de los conflictos rurales y la actuación de negros, mulatos y zambos residentes entre las orillas del mar y las nacientes cordilleranas. A las investigaciones producidas en los ambientes universitarios se suma ahora la que produce el Ministerio de Cultura, las ONG y Asociaciones Culturales (Susana Baca 2014 y Juan Martínez 2015).

2. Durante el gobierno de los Borbones y de la naciente República del Perú los funcionarios del Estado juntamente con los hacendados y comerciantes se reunieron en los locales de los gobernadores y de los municipios para combatir la plaga del bandolerismo que asolaba a muchos pueblos y capitales de provincia, pero también a las poblaciones dispersas que se encontraban asentados en los montes y afluentes de los ríos que bajaban de la sierra de Piura.

Corregidores y subdelegados se dedicaron a perseguir a las partidas de bandidos por los médanos y las quebradas andinas sin poder reducirlos ya que encontraban que los labradores y pastores de ganado los protegían en su fuga y evitando que estos delincuentes y criminales marcharon hacia la sierra de Guarmaca, las quebradas de Pariñas o el tablazo de Sechura y Payta (César Espinoza 2019a).

Otro grupo de poder lo integran los alcaldes, regidores y procuradores municipales que apoyados con grupos de vecinos comisionados se plantearon perseguir a los cabecillas y socios usando a gente especializada y portando armas de fuego contundentes para eliminar a esta plaga de gente sin gobierno que vivían dispersos en pequeños palenques al interior y las fronteras territoriales de las grandes haciendas rurales. En las sesiones de cabildo las autoridades municipales intercambiaron ideas y planes para reforzar la real cárcel y castigar a los cabecillas más peligrosos solicitando ayuda al virrey y buscar así restituir el orden social virreinal en la provincia de Piura.

En las sesiones de cabildo los alcaldes y regidores expresaron sus miedos y angustias a causa de las acciones que desplegaban las bandas de delincuen- 
tes compuestos por blancos, negros e indígenas. Este grupo de autoridades buscó usar los recursos municipales para asegurar la tranquilidad de sus propiedades y vigilar el movimiento de comerciantes y de arrieros hacia el puerto de Payta, la ciudad de Olmos y el traslado del algodón y del ganado a la pequeña ciudadpuerto de Tumbes. En estas asambleas se producían acuerdos y consensos para poner en práctica una serie de acciones para exterminar a los hombres de caminos que buscaban vivir sin trabajar ni dejar trabajar dentro y fuera de la ciudad de SM de Piura.

Las comisiones designadas van a ser pertrechadas con escopetas y puñales, mulas y provisiones necesarias para sostener jornadas de más de diez leguas de distancia, pero también de pequeñas cantidades de dinero en moneda plata para sostener a los espías e informantes dispersados al interior de los pueblos rurales y las haciendas costeñas y serranas.

El subdelegado y los alcaldes de Cabildo coordinaron acciones represivas con el Intendente de Trujillo. Los informes que manejaron las autoridades plantearon también una situación singular. Un sector de propietarios de tierras y de comerciantes habían sido identificados como el sector social agraviado por el accionar violento de los bandoleros que se movilizaban entre Yapatera-Morropon y las haciendas de Tangarará y Máncora, es decir, propiedades rurales que disponían de fronteras territoriales con los Andes y las orillas del Mar del Sur.

Entre las gentes que habitaban al interior de estas grandes propiedades rurales se dispersa las noticias y los rumores de los asaltos, crímenes y atropellos contra los viajeros, los arrieros y los labradores campesinos en medio de las pampas desérticas de Pabur o Guamará vecina al pueblo de Catacaos. Los vecinos blancos muestran su pánico frente a la presencia de estas bandas de gentes montados en caballos y mulas con los que realizan secuestros, asaltos y ataques a las personas y a la propiedad usando el trabuco y la puñaleta, arrebatándoles sus alforjas con moneda plata, sus joyas e incluso pequeńas barras de oro y plata procedentes de Sańa y Hualgayoc.

El subdelegado actúa junto con los alcaldes y regidores en su campańa policial de ofrecer seguridad a los dueńos de la tierra y a los comerciantes que distribuyen mercancías procedentes de Lima y España. Las campañas de persecución de las bandas de abigeos y bandoleros son la forma institucional de las auto- ridades del Estado virreinal de ofrecer la seguridad a las personas y vecinos residentes en los barrios de la ciudad de SM de Piura, pero también a los centros poblados rurales y parroquias existentes entre Tumbes al norte y el valle de Olmos en dirección sur. En esta ocasión los caminos, puentes y tambos van a ser vigilados para asegurar la captura de las partidas de bandidos que se movilizan durante la noche en la geografía desértica y las orillas del mar de Sechura, Colán y Payta.

Las familias de los labradores y propietarios de tierras y bosques de algarrobo vivirán un estado permanente de pánico y sospecha por el clima de inseguridad y de "terror» que imponen las bandas de abigeos y asaltantes de arrieros costeños y serranos. Del interior de las haciendas se movilizan los bandoleros para saquear también a los artesanos, los plateros, leñadores y negros que laboraban en la tina de jabón y de cordobanes en la hacienda Miraflores y Tambogrande.

El bandolerismo se convirtió en el problema principal para una elite de señores de la tierra liderados por don Luis Farfán de los Godos quien en el verano de 1786 prosiguió una campaña de movilización de los dueńos de la tierra y de los grandes comerciantes para acumular un capital monetario que les permitiera refaccionar el local de la real cárcel que estaba cayéndose y que había facilitado la fuga de muchos presos en las horas de la noche agudizándose el miedo y el terror del vecindario residente a dos cuadras de este local vecinal.

Farfán de los Godos va a ser comisionado por las autoridades del Cabildo de Piura para gestionar recursos y transferencias de capitales municipales a favor de la reparación del local para asegurar a los presos y reestablecer el orden público y continuar con la captura y liquidación física de las partidas de los temidos bandoleros rurales. El Intendente de Trujillo supervisaba los resultados logrados en esta campańa política represiva y sanguinaria para garantizar la tranquilidad social y responder las demandas del virrey de turno. En 1814 esta tarea represiva será encargada al dueño del latifundio de Tangarará y Morropón, don Francisco Xavier Fernández de Paredes, quien adelante será conocido como el marqués de Salinas y coronel del Ejército del Perú.

En efecto, el tránsito del proceso judicial al ritual del castigo de los negros esclavos y libertos se vol- 
vió periódico convirtiendo a la plaza central como el símbolo de la represión judicial para contener las fugas de la cárcel pública. Estas acciones se practicaron contra los negros e indígenas mediante pregones y ceremonias públicas en la principal plaza pública ubicado frente al local del municipio y de la iglesia Matriz. Se practicaron ceremonias públicas que buscaban ratificar la subsistencia de un sistema de autoridades legitimadas por unas acciones que asumieran la forma de castigos ejemplarizantes e intimidatorios, un símbolo de poder y dominación ante el imaginario popular como una forma de acabar con la multiplicación de las bandas multiétnicas.

Entre las conversaciones de hacendados y comerciantes se registró un ambiente de temor y de preocupación permanente por la movilización de numerosas bandas que prácticamente recorrían las márgenes de los ríos Piura y La Chira. En este intercambio de noticias y de rumores se escuchó explicar a uno de los vecinos señalando que el origen del bandolerismo estaba vinculado a la expansión de las tierras por los dueños de los grandes latifundios algodoneros y ganaderos. El bandolerismo había dejado sus huellas en la memoria y la historia oral de las familias negras, mestizas e indígenas entre los siglos XVII y XXI. ${ }^{3}$

3. El tema de estudio de los bandidos llega a San Marcos en los años 60. Se tiene noticias de que Hobsbawm llegó al Perú (O’Phelan 2018) junto a otros científicos sociales que buscaban procesar el significado de las tomas de tierras y los movimientos campesinos liderados por Hugo Blanco y losdirigentes indígenas del Cuzco y el surandino. En la EAP de Historia se nucleó un grupo de jóvenes que estudian la historia y el presente en el Perú y promueven la publicación de la revista Campesino, uno de los responsables de esta tarea académica y de investigación fue el magister Manuel Valladares. Lo interesante de esta situación es la presencia de las ideas y líderes del trotskismo en el movimiento campesino regional en el Cuzco y Ayacucho. Pero también impactaron en estos años la toma del poder en Cuba por Fidel Castro, el movimiento del Che Guevara y la forma-

3 Sobre la narrativa regional de Piura se puede consultar a Miguel Gutiérrez (1998); Teodoro Alzamora Lozano (2016); Antolin Castillo (2010 y 2012), Francisco Vegas Seminario (1955); Roque Ramírez (2013); Carlos Espinoza León (2011; Cronwell Jara (1990), y Harold Alva Viale (2010). ción de un grupo guerrillero por Luis de la Puente Uceda.

Las notas que publica Hobsbawm asocian su preocupación por comprender el mundo rural andino y el proyecto político que buscaban imponer. Desde un inicio se trató de una reflexión de corte marxista y una clara opción política. En la ciudad de Lima para esta coyuntura se han organizado dos centros de investigación liderados por dos sanmarquinos. Pablo Macera y el Seminario de Historia Rural Andina en San Marcos y Julio Cotler en el Instituto de Estudios Peruanos. Cada uno de ellos nuclea a estudiantes para elaborar un programa de trabajo que sistematizara el significado de lo que venía ocurriendo en el campo y la ciudad de los Andes del Perú (Alejandro Salinas 2016).

Ahora bien, Matari Pierre encuentra tres aportes de Hobsbawm en el estudio histórico del bandolerismo. Revisa y sistematiza las propuestas de Marx, Lefebvre y Gramsci. Encuentra que Marx trabaja el asunto de la ley de los robos de madera en Renania; Lefebvre examina a los campesinos franceses y Gramsci apunta sobre lo singular del bandolerismo sardo en Europa (Pierre, 2013: 158).

En esta dirección de estudiar el tema de la protesta rural y la revolución Hobsbawm ha escrito y publicado una trilogía compuesta por Rebeldes primitivos: Estudio sobre las formas arcaicas de los movimientos sociales en los siglos XIX y XX (1959), Bandidos (1969) y Revolucionarios (1973). A este lote bibliográfico se sumaría otro libro colectivo publicado, con George Rudé, Revolución industrial y revuelta agraria: El capitán Swing (1969).

Hobsbawm participó en lo que algunos llaman la historia radical y trabajó temas de investigación de carácter contrahegemónico. Pero es menor su adherencia a la historia desde abajo, que practican George Rudé y Edward P. Thompson. En esta orientación pesa mucho su adscripción al materialismo histórico y a la meta-narrativa de una historia que asignaba roles históricos progresistas a los obreros y no a los campesinos. De allí que al categorizar a los agentes y a los movimientos sociales utiliza los conceptos de «primitivos» o «rebeldes» para sumarlos a los movimientos protestatarios en el agro en tiempos protocapitalistas.

Para afinar esta propuesta utilizó el concepto de Gramsci de sovversivismo, "subversivismo" o protesta anárquica, no organizada en partidos polí- 
ticos, que efectúan elementos subalternos. En efecto, Hobsbawm interpreta la protesta rural como la consecuencia del rechazo de la modernización por parte de las poblaciones rurales. Esta modernización y penetración del capitalismo en las sociedades agrarias provocaría un cambio en el modo de vida de sus miembros excluyéndolos de las relaciones sociales nuevas que se habían impuesto. Los campesinos plantearon injusto este nuevo orden capitalista que expulsaba a la gente de sus tierras de labranza y otros cambios. Un sector de la sociedad optaría por el camino del bandidaje y la voluntad de retornar a un pasado y mundo idealizado.

De esta forma Hobsbawm encuentra una conexión entre el bandolerismo con el anarquismo milenarista en el libro de Bernaldo de Quirós y que para ilustrarlo usaría el apelativo de "bandidos sociales». Ahora bien, para Hobsbawm los bandidos sociales no son revolucionarios y solo los considera agentes pre-políticos. En sus libros se califica al bandolerismo como la forma más primitiva de protesta social organizada reducida a una protesta endémica del campesino contra la opresión y la pobreza y que resultaría ineficaz como fenómeno social.

En la obra historiográfica de Hobsbawm se encuentra planteada un sentido evolucionista de la historia en la que el tiempo de la historia podría terminar con episodios de luchas del proletariado contra sus opresores buscando alcanzar la justicia, combatir la desigualdad social y recuperar la esencia de una vida humana auténtica y universal. Michael Löwy y Robert Sayre (1996) plantearon que en el tiempo del Romanticismo del siglo XIX se difundió también la idea del retorno al mundo rural-campesino precapitalista. Hobsbawm revisa sus tesis y categorías de investigación y madura sus tesis transitando de su libro Los rebeldes primitivos (1959) a otro titulado los Bandidos (1969), explayándose en este último en el examen del bandolero social.

Hobsbawm precisó que sus tesis sobre el bandolerismo lo sustentaban las ideas que encontró en las investigaciones de Fernand Braudel y su libro El Mediterráneo y el mundo mediterráneo en la época de Felipe II (1949). Es en este libro que va a encontrar la idea de que la superpoblación es la causa más importante para la emergencia del bandolerismo. Una propuesta explicativa que Braudel lo recoge del malthusianismo.
Hobsbawm buscará establecer una separación entre los criminales y los bandidos. Señala que estos últimos no son criaturas monstruosas sino individuos que mantienen una adaptación problemática a las estructuras capitalistas.

Una revisión de este último trabajo mostró que su unidad de estudio carece de poco respaldo documental de fuentes primarias y de material de archivos y que abusa de las fuentes literarias para las explicaciones que buscaba fundamentar su tesis. Careció por tanto de una base documental empírica e histórica y también se le señala que no pudo desprenderse de una teoría eurooccidentalizante. Hobsbawm llegó a plantear homogeneidades y la reproducción de modelos de bandolerismo social en su propósito de reforzar su tesis de que no constituían una fuerza histórica para el cambio social, una tesis política que ya en ese tiempo se difundían por otras fuerzas académicas y políticas vinculadas al maoísmo (Isaac Deutscher 1964).

Hobsbawm revisó sus publicaciones y asumió un conjunto de críticas a sus tesis de trabajo. En las ediciones posteriores de su libro los incorpora madurando sus posiciones para el debate. Así, por ejemplo, asumió una crítica de fondo que le planteó el antropólogo Anton Blok (1972) quien señaló que Hobsbawm no reconstruyó las bases estructurales de la sociedad ni explicó como surgían los bandidos y menos dio una explicación detallada sobre las estructuras de poder político de las sociedades rodeadas por la fuerza del capitalismo occidental.

En adelante Hobsbawm insertó un epílogo y el capítulo titulado "La economía y la política del bandolerismo» en las nuevas ediciones de Bandidos. Esta vez planteó que los bandidos necesitaron de intermediarios que los pusieran en relación con el resto de la economía local y con las redes más amplias del comercio.

Blok también asegura de que hubo un gran número de bandidos y ladrones sin ninguna afiliación social. No niega la existencia del «bandolerismo social», pero lo interpreta más como aspiración social de los campesinos que como una realidad social. Para Blok el bandolero social existió sólo en la mente de su público.

Estas críticas obligaron a Hobsbawm a realizar una serie de agregados y de precisiones sobre la naturaleza del bandolero social en los años noventa. En 
1991 Hobsbawm explicó lo que para él es un bandolero «social»: «Es social [el bandolero] en la medida en que no hace daño a los campesinos, es considerado diferente de un simple criminal, y es considerado de utilidad pública». De esta forma Hobsbawm transitó en su concepción histórica de un sujeto que en un principio fue categorizado como un rebelde por sus actos a una valoración de la población. En buena cuenta, Hobsbawm planteó manejar el concepto de «bandolero social» deslizando su examen hacia el campo de la subjetividad.

De esta forma, Hobsbawm llegó a admitir en 1997 una nueva propuesta metodológica para entender a los bandidos y a la sociedad que la rodea. Sostiene esta vez que el modelo centrado en las funciones de la protesta social no es un marco conceptual adecuado para un análisis histórico del bandolerismo.

Esta vez reconoció que los bandidos sociales no realizaron la defensa de los intereses de las clases humildes y que, por el contrario, la mayoría de los bandidos conocidos no fueron sociales, sino delincuentes pertenecientes al hampa y a la mala vida preindustrial de los marginados sociales y de los criminales.

El último libro en el que trabaja sobre la protesta rural y los bandidos es el que se titula Gente poco corriente: resistencia, rebelión y jazz (1998). Aquí construyó un capítulo sobre la guerra de Vietnam y el examen de un guerrillero buscando encontrar similitudes y diferencias con un bandido social. Así, esta vez encontró que ambos personajes tenían en común la dependencia de la población civil de su entorno y una ideología conservadora. El guerrillero que logra el cambio y el éxito con la nacionalización. Describió la lucha contra un ocupante extranjero orientado por partidos políticos y movimientos nacionales.

4. En el siglo XXI se produce un incremento en la producción historiográfica sobre el bandolerismo imponiéndose la revisión crítica de algunos de los estereotipos y construcciones históricas que Hobsbawm planteo en sus estudios sobre los bandidos. En las polémicas políticas y académicas se registró una alta politización de los bandidos sociales y de los movimientos campesinos.

Ranahit Guba (Subaltern Studies), criticó y se opuso a la hipótesis de los movimientos apolíticos planteados por Hobsbawm. Planteó todo lo contrario y señaló que todos los movimientos rurales en la
India colonial tuvieron un componente político contra el sistema de propiedad de la tierra y de los terratenientes, así como el endeudamiento campesino.

Pero Hobsbawm mantiene sus proposiciones de investigación y reafirma su tesis sobre la «baja clasicidad» del campesinado y su escaso potencial revolucionario. Esta visión del bandolero le sirve a Edward P. Thompson para conceptuar su tesis sobre la «economía moral».

La historiografía sobre esta temática avanzó gracias al debate que provocó la propuesta de Hobsbawm. Otro asunto que se critica es la limitación del fenómeno del bandolerismo al período de penetración del capitalismo en el campo y no se presta la atención de este fenómeno para períodos posteriores.

En definitiva, los estudios críticos que revisitan la obra de Hobsbawm tienden a aceptar la tesis de manera general de que el bandolerismo de la Edad Moderna consistió en luchas de facciones mientras que esta práctica a partir de finales del siglo XviII estará ligada a las dificultades puntuales para subsistir que experimentaron algunos individuos pobres.

5. La obra de Eric Hobsbawm contiene muchas hipótesis iniciales y conceptos popularizados como el de «rebeldes primitivos» o «bandido social» que han provocado un intenso impulso a la investigación de la sociedad rural y el campesinado en los Andes.

Con la ruptura del movimiento comunista internacional y la emergencia del comunismo chino se agrava el debate y se profundiza la revisión de los conceptos, la metodología y las fuentes empíricas que sustentan el modelo de Hobsbawm. El maoísmo propone al campesinado y sus formas de lucha como una fuerza histórica revolucionaria bajo alianzas y uso de coyunturas históricas específicas. La historiografía sobre el estudio de las sociedades rurales en América latina le debe mucho a Hobsbawm pues sus tesis obligaron a debatir las investigaciones orientadas no solo al ámbito académico sino a su utilización para las prácticas políticas (Guido Lissandelo y Eduardo Sartelli 2013:105-138).

Una de las líneas de trabajo fue la de estudiar la figura del bandido y analizar y comprender sus vínculos y relaciones con la sociedad rural y los cambios que introducía el capitalismo en el siglo Xx.

Los historiadores examinan la sociedad rural y su mundo interior, así como el despliegue de todo 
un entramado de estrategias delictivas que desarrollan los campesinos para resistir el avasallamiento de la economía mercantil capitalista y asegurar la subsistencia familiar. Su accionar junto a otras agrupaciones sociales representó sin duda una forma singular de resistencia y de construcción de alternativas a los caminos del cambio social que impone la fuerza del capital y la emergencia de la ciudad y el mundo urbano.

La sociedad y la comunidad rural contienen en su seno una diversidad de fuerzas de cambio que se expresan mediante el conflicto social. El delito no es el único y exclusivo mecanismo utilizado o dedicado por individuos o grupos que la integran.

Los estudios realizados confirman la idea de que los bandidos o las bandas organizadas de fugados o bandoleros no son la única o principal expresión de conflicto en el mundo y la sociedad rural, sino una forma más, a veces muy excepcional y marginal, del tejido de las relaciones conflictivas que daban forma a la sociedad rural (Norberto Ferreas 2003).

Esta orientación ha impulsado en el siglo XXI nuevas investigaciones por los historiadores para el examen de los procesos de movilización social y cambio político en el mundo rural contemporáneo. Este cambio metodológico plantea que la mirada del historiador ya no solo se limite a realizar un cómputo de las acciones realizadas por las bandas organizadas, las rebeliones y las revoluciones sometido a un relato teleológico del pasado.

Bajo esta orientación estos listados de las denuncias, expedientes y sentencias judiciales cargados de resistencias a la autoridad, asalto a las haciendas y poblados rurales, el contrabando y la evasión de impuestos, la violación de mujeres y las deserciones, las estafas y los robos a los seńores de la tierra, los daños e incendios por venganzas, las roturaciones ilegales y la quemazón de capillas, el pastoreo abusivo y el atraco a los arrieros etc., ahora pueden servir para descubrir la existencia y el funcionamiento de otros mecanismos claves para conocer los sistemas de la defensa de intereses y derechos comunitarios frente a las autoridades, las pequeñas élites o el propio Estado (César Espinoza 2019: 267-290).

La documentación judicial de archivo nos permite ahora introducirnos al mundo social rural para conocer los abismos existentes entre el derecho indiano y la práctica social, el mundo social asimétrico y la reproducción de un modelo colonial ilegal en las regiones y provincias para conocer la naturaleza de las acciones de protesta colectiva que transitaban de explosiones de odio campesino hacia movimientos sangrientos que rompían la paz social y de vida de señores y de campesino labradores de la tierra y ganaderos cotidianos.

En la actualidad se utiliza la categoría de «formas cotidianas de resistencia campesina» que nos ayudan a comprender mejor las acciones de los campesinos y a revitalizar el concepto de «lógica campesina» y reconsiderar o ampliar otro concepto como el de la politica en el mundo rural. (Antonio Escobar 2017: 208-217 y Arlene Renk 2017: 307-319).

Se intenta ahora profundizar el conocimiento de las acciones de la resistencia campesina para poner al descubierto la existencia de un tejido de complejas relaciones sociales y de poder que descarta toda consideración apolítica del campesinado en los Andes del Perú.

Nuestra investigación busca ahora rastrear las huellas de toda una cultura afrodescendiente de resistencia en el campesinado y de la gente de la ciudad desempolvando los fondos documentales de primera mano en los archivos judiciales regionales como Piura y Trujillo.

\section{Los subdelegados y justicias mayores de Piura se enfrentan a dos fuerzas sociales de resistencia en un espacio regional: los cimarrones salteadores y a un bandolero famoso, José Sapata (a) Palomo y su cuadrilla $^{4}$}

Entre 1815 y 1816, concluida la represión de las juntas de gobierno en el sur andino y reprimido a los individuos y grupos devotos y cercanos a las ideas constitucionalistas y liberales de la Cortes de Cádiz, se producirá el retorno de Fernando VII al trono en España. Abascal está obligado a reiniciar su combate contra los enemigos políticos en la costa norte, una extensa franja regional en la que un sector y fracciones de la elite criolla, en algunas ciudades había mos-

4 Archivo Regional de Piura (ARP). Año 1815. Intendencia, Legajo 68, Expediente 1406. Cuaderno Primero de los Autos Criminales seguido de oficio por don Francisco Xavier de Fernández de Paredes, comisionado por el Superior Gobierno y por la Intendencia de la Provincia de Trujillo. En adelante, los folios enumerados corresponden a este legajo. 
trado su intención de radicalizar los decretos y mandatos de la Cortes de Cádiz desde 1812 para quebrar la dominación que había establecido Abascal desde el año de 1806.5

En efecto, para reprimir cualquier signo de rebeldía o cuestionamiento a su gestión Abascal coordina con el Intendente de Trujillo, don Vicente Gil de Taboada y el subdelegado de Piura, don Juan Asencio Monasterio, en la primera mitad del ańo de 1815, ordenando una variedad de acciones políticas y militares para reprimir y exterminar lo que se calificaba como un movimiento social peligroso para la tranquilidad virreinal, liderado por José Gallo (a) El Palomo, quien había llegado a la ciudad de San Miguel de Piura y se había estacionado en Querecotillo acompañado de un grupo de gente de color negro procedentes de la ciudad de Lima y a quienes se les calificaba de asesinos, salteadores y ladrones.

Todo empieza cuando desde la ciudad de Trujillo en 16.03.1815, el Intendente don Vicente Gil de Taboada le remitió un escrito a don Francisco Xavier Fernández de Paredes, alcalde de primer voto y autoridad encargada temporalmente de la ciudad de SM de Piura. ${ }^{6}$ En esta carta le recomienda «recelar» de las acciones que despliega un sujeto llamado José Gallo (a) El Palomo, a quien califica de ladrón y que montado en su caballo saíno y portando su trabuco caminaba abiertamente por las tierras cultivadas y potreros de ganado pertenecientes a la hacienda de Tangarará.

Aún más, en medio de una desesperación creciente, desde la ciudad de Lima en 29.03.1815, el virrey Abascal, Marques de Concordia, le escribió directamente a don Fernández de Paredes, alcalde de primer voto de Piura para avisarle que fue el propio Síndico Procurador de la ciudad de SM de Piura quien le informó sobre el peligro que vivía la provincia de Piura porque incluso al interior de su hacienda se encontraba residiendo un sujeto peligroso llamado José Gallo (a) Palomo, un «salteador famoso» que se

5 Scarlett O'Phelan. 2013. Abascal y el fantasma de las conspiraciones, pp. 121-146; Elizabeth Hernández. 2013. Autonomía y monarquismo en un espacio regional: Piura en la consideración de Fernando de Abascal, pp. 147-167. En: Scarlett O’Phelan y George Lomné. Abascal y la contra-independencia de América del Sur. IFEA, Lima, Perú.

6 Sobre el tema de los miedos se puede consultar a Bernard Lavalle'. Cap. 3. La "Grande Peur» del año 1812 en Trujillo y sus valles; pp. 87-98. 2018. En: Los cerros de La Libertad. Esclavos cimarrones en Trujillo Colonial. Editorial Universitaria Villarreal, Lima, Perú. había fugado el año anterior de la ciudad de Lima. Termina señalando que es urgente que se capture a Palomo y se le aplique el escarmiento necesario para evitar cualquier desgracia total (f.2).

Todo parece indicar que hasta mediados de ese año nada habían podido cumplir las autoridades civiles y militares en Piura y ejecutar el mandato de Abascal. En consecuencia, en 06.10.1815, don Juan Asencio Monasterio, subdelegado de Piura le escribió otra carta a don Fernández de Paredes para avisarle que «hallándose esta ciudad y los lugares de su Partido atemorizados con los continuos robos que está cometiendo fulano Palomo, más un negro que lo acompańa y otros varios que se le han agregado» (f.3), le reitera que prosiga en la campaña militar don Fernández de Paredes acompańado de su escuadrón de soldados y procedan a capturarlo y a embargarle todos los bienes.

Mas tarde, en 17.10.1815, el subdelegado Monasterio remitió otro escrito a Fernández de Paredes para recordarle que el virrey Abascal se mostraba preocupado en la ciudad de Lima porque el bandido Palomo se movía por los caminos de haciendas y pueblos con la mayor tranquilidad. En esta carta Abascal le alcanzó varias recomendaciones para que pueda cumplirse lo mandado: que «es necesario que a la posible brevedad y con toda precaución procure U., juntar una fuerza competente para aprehender o exterminar al famoso salteador N. Palomo que, en compañía de un negro asesino, está en las inmediaciones de esa ciudad causando muchos dańos, y espero que U., logre con su actividad y celo libertar a ese pueblo de semejantes extorsiones». ${ }^{7}$

Para iniciar la campańa militar de captura de Palomo, el subdelegado Monasterio convocó a una sesión del Ayuntamiento de Piura; esta vez los alcaldes y regidores se comprometen a otorgarle el apoyo a la fuerza militar para lograr finalmente la captura del "famoso salteador N. Palomo, un negro asesino que lo acompaña y otros que se le han agregado». El subdelegado Monasterio asegura al virrey Abascal de que tanto las autoridades como los vecinos de Piura se han comprometido en suministrarle "todos los auxilios que pidiese tanto de armas como de gastos» (f.5).

7 Carta del marqués de la Concordia 23.10.1815 a señor subdelegado de Piura (f.4). 
Sin embargo, el virrey Abascal se encuentra nuevamente furioso por los escasos resultados logrados para que se cumpla su mandato pues ya se estaba terminando el año y Palomo seguía movilizándose por los médanos y bosques de algarrobo dorados sin mayor preocupación. De tal forma que otra vez desde la ciudad de Lima, Abascal remitió una nueva carta fechada en 24.11.1815 reiterando la urgencia y la necesidad inmediata de que Palomo y su banda sean apresados por el subdelegado de Piura. El contenido de esta carta expresa la angustia de Abascal y las recomendaciones que debe seguir el subdelegado para capturarlo y exterminarlo: dice: «debiendo U. perseguir de todos modos al ladrón famoso José Sapata Palomo, que con otros malvados aflige a ese vecindario asaltando en los caminos y aun en las mismas haciendas, como anteriormente se lo tengo presentado, deberá usted escoltar sus expediciones con la fuerza armada, que juzgue convenientes a su seguridad y la de los demás individuos que le acompañen, la que en caso de resistencia hará usted que obre como debe en tales circunstancias: lo que le prevengo en contestación a su carta de siete de octubre último. Dios guarde a Usted más años. Lima 24.11.1815. Abascal (f.7).

Esta correspondencia enviada por Abascal a Piura finalmente va a caer a manos de don Francisco Xavier Fernández de Paredes, latifundista y alcalde ordinario de Piura. La novedad que incluye en estas últimas es que junto a las autorizaciones para liquidar físicamente a Palomo se ordenó en 12.12.1815, la captura y prisión de dos «amasio» (amantes) que disponía José Gallo (a) el Palomo, dos mujeres que convivían y que una de ellas vino de Lima, María Andrea Regalado y la otra, Dolores Campos, era natural de Querecotillo, Piura (f.7v).

En la correspondencia interna que maneja el subdelegado Monasterio a comienzos del año de 1816 se encuentra varios informes sobre las campańas que había iniciado sin poder llegar a capturar a Palomo. En efecto, para el primer tercio de este año se pueden registrar las siguientes acciones menudas. En 11.02.1816, Fernández de Paredes pasó montado en su caballo y escoltado con seis soldados y un oficial por el sitio de La Vaquería en la hacienda de Yapatera, buscaba entonces capturar personalmente a JS Palomo, ya que para esto había solicitado el apoyo de un personaje del lugar llamado Isidro Sata; todo formaba parte de un plan y Fernández de Paredes estaba confiado en realizar la captura acompańado de esta patrulla con soldados armados y que luego de llegar a la hacienda de Nomala y llamar a don Manuel Carrasco, su dueño, le comunicaron la mala noticia que le provocó mucho más miedo que antes. Le avisaron esta vez que por un encargo oral que le hizo llegar Miguel Meca (a) «El Viejo», un desertor del Fijo de Lima, a JS Palomo, este tomó su caballo saíno y logró fugar hacia otro monte vecino. Y averiguando mucho más sobre este asunto imprevisto, tiempo después le informó José Correa, que en realidad quien había efectuado este aviso oportuno a Palomo fue Manuel Antonio Sánchez, un teniente de la segunda compañía del Escuadrón de Querecotillo (f.8). El hacendado cavila y llega a la conclusión de que Palomo tiene vinculaciones en muchas esferas sociales e instituciones que lo apoyan para movilizarse en situaciones de peligro como había ocurrido en esta oportunidad.

Otra acción que practica en 10.02.1816 el hacendado y alcalde don Fernández de Paredes fue la de ordenar a Domingo Talledo, Ayudante Mayor del Escuadrón, para que acompañado de un grupo de doce hombres montados a caballos y con sus armas de fuego pasara al sitio de Querecotillo para perseguir y capturar a un sujeto llamado el «Negro», que era un conocido y compańero íntimo de las andanzas de JS Palomo. El resultado final fue nuevamente negativo pues Palomo y JM Izquierdo (a) «El Negro» habían prácticamente pasado a la clandestinidad y andaban por los montes de Yapatera y Tambogrande protegidos por los campesinos y labradores de la tierra (f.8).

Mediante un escrito fechado en 10.02.1816 don Fernández de Paredes busca explicar al subdelegado lo que había sucedido en esta ocasión: "con noticia de que Jose Sapata, el Negro y otros facinerosos se hallaban en el sitio de Querecotillo protegidos de una grande porción de vecinos y resueltos a hacer frente a la expedición, de que tenían noticia, atricheraronse en el monte de Juan Manuel Flores, en el callejón del río; pasó el día 17 a Querecotillo escoltado con 30 hombres, y llegado a la quebrada de la hacienda Nueva, se avistaron como a 8-10 cuadras a cuatro hombres en caballos con tres escopetas, estos huyeron, pero cayo uno de un balazo, este se llamaba Gregorio N (a) «Siete Cintas» o "Tigre»; luego la gente fue a la orilla del rio frente a la hacienda de Somate y por allí pasaron los reos y no los soldados quienes fueron 
por el vado. Luego los persiguieron por ocho días en el rio Piura y La Chira» (f.8v). Lo que se observa es una acción militar que buscaba liquidar físicamente a los que con el discurso de «ladrones» se los calificaba de enemigos de España pues crecía el miedo a que este tipo de gente podría transitar a transformarse en amigos de los insurgentes o que los mismos bandidos se convirtieran en montoneras al servicio de una de las facciones sociales de una elite declarada enemiga de Abascal. ${ }^{8}$

Avanzado el tiempo y ya un poco recuperado de esta malograda experiencia militar, nuevamente don Fernández de Paredes en 01.03.1816 con el apoyo esta vez, de una parte del escuadrón de Dragones de Amotape ordenó la ejecución del embargo de los bienes de los reos JS Palomo, el Negro José Izquierdo, María Andrea Regalado, Dolores Campos y otros cómplices. Con esta acción se buscaba intimidar a la población y disciplinarla a favor de las fuerzas del virrey Abascal.

Fernández de Paredes se siente muy preocupado porque ahora tiene que movilizarse entre la ciudad de SM de Piura y su casa-hacienda de Tangarará acompańado de una patrulla de negros armados que lo protegen de cualquier ataque como ocurría en esos días contra los viajeros y comerciantes que usaban el camino real de los Yngas que cruzando el río La Chira desde Amotape se dirigía a Máncora-Pariñas y a la ciudad- puerto de Tumbes. La captura de Palomo no había sido posible y ahora inicia un proceso legal contra sus dos mujeres amantes, María Andrea Regalado y Dolores Campos. Piensa y está convencido de que, presionando a estas mujeres, José Sapata (a) Palomo, podría acercarse y negociar su libertad y encontrar una salida a lo que la vecindad le reclama, que la provincia de Piura esta asolada por bandas de malhechores que se dedicaban a realizar robos públicos, asesinatos y a violar las leyes y la justicia virreinal que administra el virrey Abascal. ${ }^{9}$

En esta dirección solicitó que se presentaran a declarar varios testigos para que respondan a un cuestionario con preguntas elaboradas (f.10).

8 Esta línea de investigación es trabajada por una densa historiografía contemporánea. Se ha consultado a Di Meglio (2007 y 2013); Fradkin 2005; Tardieu (2013 y 2018) y Javier Tord Nicolini (1977).

9 ARP: 1813, Intendencia, Causas Criminales, legajo 68, expediente 1832. Criminales contra Rufino y Juan de la Cruz Adanaqué, por la muerte de Mateo Villegas, los indios de la hacienda de Guápalas, en la bajada de Lacho, camino de Vicús.
La primera persona que declara es Dolores Campos, edad 20 años, quien afirma que no sabe escribir. Comienza su testimonio señalando que recuerda que un día José Sapata Palomo salió de Querecotillo en dirección a "Lamor» y José María Izquierdo hacia la ciudad de Piura, agrega que este último salió acompañado de José Vargas y el «Manco» por el sitio llamado El Salto; y que esto lo confirmó Pablo N. (a) "El Cojo», y que todos marcharon juntos. Y fue que al quinto o sexto día empezaron a regresar de uno en uno desde la mañana hasta caer la tarde. Así es que vio como Palomo trajo una alforja con una fuente, una palangana chica y cuatro cucharas de plata; y que José María Izquierdo también le mostró un ovillo de pabilo torcido de varias hebras y encerado y el «Manco» un sombrero de paja blanca.

Recuerda también que fue por esos días que escuchó las noticias de un robo en la casa de Gregorio Palacios, y que lo difundió el peinero Manuel Palacios. En Querecotillo se produce un movimiento singular de idas y vueltas de las patrullas que recorrían y visitaban las casas hasta el sitio de La Tina. También recuerda que llegó esa vez «El Nato» de las Panchillas con su ropa de sastre y vestido de beato. Y que por orden de Palomo se guardaron las especies robadas en su casa y debajo de un colchón durante el tiempo de un mes. Allí fue que aprovechó para preguntarle a José María sobre este robo y que este le contestó que lo hicieron juntos Pedro «Malo», «El Nato», Vargas, «El Manco», «El Negro» y José Sapata Palomo (f.10v).

De igual forma, recuerda también que oyó decir que en otra ocasión le robaron a Sebastián Garrido. Y que esta vez participaron $\mathrm{El}$ «Negro», JM Vásquez, José Vargas, Salvador de la Cruz y que realizada la distribución en esta ocasión le tocó a Palomo la cantidad de 200 pesos en moneda plata, una onza de oro y a cada uno de los participantes 50 pesos en moneda plata. Y que respecto a lo sustraído por José Sapata Palomo a este le tocó una vasenica, una estribera y una palangana chica de plata. Y que toda esta plata fue fundida en Querecotillo por el platero Mateo y que finalmente le dio a José María Izquierdo la cantidad de 25 pesos.

Explica también que en esa ocasión el negro José María Izquierdo había sustraído cinco piezas de tela de bretaña, una cadena de oro con 13 castellanos, un pedazo de hebilla de pie, una hebilla de sombrero, 
una cantidad de oro en polvo por 13 castellanos, tres pares de media de seda y un par de pistolas. Finalmente, señala que Vargas se trajo un reloj y una pieza de sarasa Marsella.

Fue en otra ocasión y una noche cuando disfrutando de un cigarro Palomo le contó sonriendo que todo lo que hacía era "por dar gusto a un amigo [que] se hallaba en estos trabajos» (f.11). Y que este amigo se llamaba Isidro Ortiz. Que este es un hombre «maduro» que le encargó una carta con Vargas y que le regaló un caballo ya que por los líos que tenía por su hacienda quería sentir la venganza este Ortiz. Relata además que le contó esa vez que la conversación terminó diciéndole a Palomo que «Dios no mandaba matar a nadie» (f.11). Y que finalizado este comentario se dio cuenta esa noche que Palomo ya tenía una herida en el «bacio» y que esa vez le curó una mujer llamada Bausa con una candela.

En suma, recopilando este comentario y otras noticias señala que también Palomo y su grupo hicieron otro robo en el camino a Payta; esa vez caminando entre los médanos y las dunas participaron José María Izquierdo, Pablo «Malo», el Negro «Uribe» y Jacinto Tomasongo, y que el monto del robo alcanzó los 500 pesos. Fue una oportunidad en la que se atacó a Valentín Guerrero, marido de doña Josefa Salguero y hermana de Mariano Salguero (f.11v). Ya transcurrido un poco el tiempo el "Negro» llegó a devolver 220 pesos y ya preso declaró que solo pudo gastar 20 pesos y que otros 250 pesos restantes lo retuvieron en su poder el sujeto llamado Pedro «Malo». Haciendo memoria recuerda que en ese ataque el negro José María Izquierdo quiso matarlos a los mencionados, pero ocurrió que los otros participantes intervinieron y se opusieron diciéndole que "eran de su tierra».

También agrega a su confesión que lo hace con mucha cautela señalando "que mientras los estaban persiguiendo aquí querían asaltar las casas de la hacienda del Juez ante quien declara y de don Bernardino Vásquez que le acompañaba pues las consideraba desamparadas» (f.11v).

Un asunto que no olvida es que en la romería religiosa de Chocán, ${ }^{10}$ el negro JM Izquierdo quiso ma-

10 La fiesta religiosa de Chocan que ya se conoce a finales del siglo XVII, hoy es celebrado con el nombre de Festividad del Señor de la Buena Muerte de Chocán; es una fiesta pública que se celebra en 2 de febrero de cada ańo y congrega a multitudes de fieles cristianos. Ver: http://arzobispadodepiura.org. Consultado en 12.12.2018. tar a Cirilo Nole con una escopeta y que esa vez solo pudo detenerlo Palomo para evitar una desgracia, y de igual forma, otra vez intentó matarlo en el cepo de La Punta, pues este Nole había sido un hombre comisionado por el subdelegado de Piura para capturarlo y que a todo esto se opuso con mucha furia Palomo y logró detenerlo. En otro momento de un día que no recuerda el negro JM Izquierdo estaba en la orilla del rio La Chira esperándolo con la escopeta lista para matar a Nicolás Palomino quien para su suerte no se apareció por ese lugar. Ya emocionada Campos dice que en Querecotillo todos los que allí viven y saben que este negro hablaba y decía en voz alta que "pues matando a los que hacían cabeza, los demás se largaban» refiriéndose a los que servían al subdelegado como fueron Bernardino Vásquez y Cirilo Nole.

Así explica que durante la estancia en la que estuvo en Querecotillo sabe que la vida del negro JM Izquierdo es muy «alarmante» pues recuerda que cuando este se encontraba en la ciudad de Lima él tenía aquí una "amacia» y que teniendo noticias de que se iba a casar con otro la mató a puñaladas.

Otro asunto que se menciona en esta declaración es que este grupo de gente también buscaba obstaculizar la justicia recurriendo a las autoridades y presentando papeles para aborrecer al subdelegado. Así lo hicieron con el juez de Querecotillo, quien habiendo empezado una acción de embargo de bienes compuesto de fierro y una silla a Juan José Zapata, pariente de Palomo, al poco tiempo esta autoridad tuvo que devolverlo pues los afectados acudieron a los abogados y otras autoridades (f.12).

No olvida agregar que también escuchó hablar entre ellos de que en la ciudad de Lima mataron a siete caballos de la patrulla que los perseguía y que todo fue hecho cuando dirigía esta tropa un comandante llamado Vigil. No olvidaban que en esta ocasión murió uno de los compañeros de Palomo «cuyas resultas atribuyendo suerte a un milagro de la Virgen se resolvieron a abandonar el lugar y venir a vivir a este» o sea a Piura.

Participa también de la noticia de que el tal Palomo tiene dos heridas en su cuerpo, una entre las costillas, abierta y «afistulada» con una munición adentro que lo recibió cuando eludió a una patrulla que lo perseguía, y la otra herida la tiene ya cicatrizada en la ingle, que en este caso se lo hicieron con un 
rejón que le aplicó un hombre europeo en un combate que tuvieron (f.12).

El tiempo en que se produjo todo lo mencionado fue cuando se vivía un momento de mucha propaganda y de alegría porque se difundía la noticia de que en España había retornado al gobierno don Fernando VII. Y que ya en 1815 Palomo ya es un hombre famoso porque había recorrido muchas ciudades y atacado varias haciendas entre Tumbes y la ciudad de Lima. Todos sabían que de esta última ciudad trajo muchas bestias y cosillas de poco valor. Y que fue durante este tiempo que su «amacia» era Maria Andrea Regalado, una mujer a quien Palomo le encargó guardar un total de 550 pesos en moneda plata. Y que esta al poco tiempo les encargó a dos sujetos del pueblo de Santiago de Cao la cantidad de 200 y 350 pesos para que después Palomo le pidiera a su hermano Salguero que recuperase el dinero y se lo entregara.

Recuerda también que una noche el negro JM Izquierdo le contó de un robo que realizó apoyado por una mujer conocida como la "Limeńa» y que esto fue posible hacerlo logrando ganarse la confianza de una criada para poder entrar en la casa y robar muchas onzas de oro, alhajas, una botella de perlas y ropa fina de uso.

Sobre estas vestimentas también sabe que Palomo tiene una saya en la ciudad de Lima y que no se lo había entregado a su amante Regalado, sino que lo conservaba para venderlo. En esa ocasión, la samba le había dicho directamente "que, si quería fornicar de balde, y Palomo le repuso que arto le había dado, y que si todavía quería robarse para botar la plata como botaba en Lima" (f.13). Buscando conciliarse ante este rechazo, Regalado le solicitó a Palomo que le donara una silla de plata, pero la respuesta fue negativa. Y que todos saben que Palomo es un hombre muy celoso y que esto se puede verificar porque a un amigo de Regalado le cortó la nariz con una navaja de barba.

En buena cuenta, para ella Palomo es un hombre que viaja mucho y que le gustaba vivir en la ciudad de SM de Piura y en Querecotillo. Recuerda que Palomo y el negro JM Izquierdo regresaron juntos de la ciudad de Lima y que luego se fueron a vivir a la casa de Simona Sapata, una tía de José Sapata (a) Palomo, y ocurrió que hacía ocho meses que el negro Izquierdo se había ido con su «amacia» a la casa de Pedro José Agurto. Fue la oportunidad en la que Palomo pasó a la casa de Dolores Campo para allí recibir al negro Izquierdo y permanecer juntos durante tres meses.

Es por esta razón y amistad que ambos sujetos vivían casi siempre alertas a la llegada de las patrullas militares y de gente enviada desde la hacienda y que los que le avisan sobre los peligros de estas campañas de capturarlo son Palacios, el «Ñato» de las Panchillas y Salguero. A este último lo apoya Miguel Meca (a) «El Viejo» y Manuel Antonio Sánchez.

A todo lo expuesto Dolores Campos termina señalando con un gesto de amargura que en este tiempo «tuvo la desgracia de tener amistad ilícita con José Sapata Palomo».

A continuación, se presenta a declarar la otra mujer que vivió con Palomo, su nombre María Andrea Regalado, edad 30 ańos. Ella empieza señalando que conoció a JS Palomo en la ciudad de Lima cuando visitaba la cárcel y que al poco tiempo logró fugarse para luego terminar refugiado en la hacienda de Pio Plata, en La Molina. Aquí los amigos que encontró le dieron dos camisas, 50 pesos en moneda plata y un caballo para que fugase a otro lugar (f.13v).

También explica que después tuvo noticia de que el negro JM Izquierdo vivió en Querecotillo y que lo perseguían las autoridades locales pues había cometido un robo a un caballero conocido de la ciudad de SM de Piura. Recuerda que Palomo entabló amistad y conoció al negro Izquierdo en la ciudad de Lima cuando este se dedicaba a cargar alfalfa entre el Callao y Malambo. No puede precisar si ambos hombres vivieron juntos en la ciudad de Lima, y solo sí recuerda que ella vino después siguiendo a Palomo cuando abandonó esta ciudad y llegaron también a vivir un tiempo en el sitio de Querecotillo. Agrega, que ella sí está segura de su regreso a la ciudad de Lima en 25.06.1815 para luego retornar a Querecotillo y que lo hizo en el día de la fiesta de la Candelaria.

En efecto, fue por esos días que tomó la noticia del patrullaje que realizaba el comisionado y comandante militar don Francisco Xavier Fernández de Paredes y que por ese motivo buscó guardar la distancia con estos dos hombres mencionados. Recuerda también que un día esta autoridad se le acercó para conversar con ella y que le pidió le entregase algunas cosas como una silla, una cadena y unos faluchos que decía que los tenía Palomo y que ella le contestó que no podía hacerlo porque no los tenía en su poder (f.14). 
Es por esta difícil situación que vivía y acosada por las autoridades que perseguían a los dos hombres mencionados que recuerda cómo «Palomo la había seducido en Lima, y que por eso vino acompanándolo, aunque su mala amistad siempre fue con ánimo de casarse». Así que para hacer realidad este proyecto personal de su matrimonio en la que pensaba realizar buscó conocer y acercarse a la madre de Palomo, y también a una hija suya y a reconocer las bestias que poseía en este pueblo (f.14). Pero todo fue en vano porque ocurrieron otros acontecimientos que se cruzaron en su vida y que ella ni sońaba que todo esto podía ocurrir.

Relata que entre los asuntos que le conciernen, una tarde Palomo le entregó un encargo especial para cobrar un dinero en el pueblo de La Barranca a «Manongo" Montoro por la cantidad de 200 pesos; y que esa vez sí tuvo este contacto con Montoro para realizarlo, pero en el camino tuvo que fugar porque le avisaron que estaba en complicidad con el subdelegado.

Veamos ahora la declaración que realiza José María Izquierdo, hombre de casta negra, edad 27 años y dice que no sabe escribir ni firmar. Este testigo confirma que sí robaron junto con Palomo en la hacienda de Sebastián Garrido. En aquella ocasión participaron José Vargas, "Chapeta» y Salvador de la Cruz. Cuenta que el grupo llegó a la casa a las siete de la noche y que primero Palomo preguntó por una mujer cuyo nombre no recuerda y que el negro JM Izquierdo entonces bajó de su caballo e ingresó a la cocina para encender un cigarro. Observó preocupado que en ese momento en el lugar había muchos "cholos" y que aprovecharon un descuido para capturar al dueño y colocarlo en un cepo. Después pasaron a tomar lo que podían encontrar en la casa y subidos a sus caballos fugaron hasta llegar al sitio de Somate y de allí pasar a Querecotillo en una sola jornada. Añade que este asalto fue conversado y que acordaron que primero fuera enviado Salvador de la Cruz para que se informara si había o no dinero. Los que concurrieron a este asalto como "Chapeta" y Salvador de la Cruz vivían ahora en Querecotillo, un lugar en la que conducen sus chacras y mulas (f.15v); agrega que el tal Vargas es de Lambayeque. Y que Palomo y el negro JM Izquierdo estuvieron antes viviendo en la ciudad de Lima hasta el mes de octubre de 1814 (f.15). Izquierdo mantuvo en ese tiempo dos mulas pero que finalmente estas bestias terminaron siendo embargadas por las autoridades. Lo que no pasó así con Palomo que todavía conserva varias bestias y una silla chapeada con plata.

Agrega informando que es evidente que este grupo de hombres sabían acerca de los cambios que estaban ocurriendo en la provincia de Piura. Y que estaban enterados de que había llegado un decreto del virrey Abascal que ordenaba a Fernández de Paredes para que organizara la captura de JS Palomo y que encontrándose este último descansando enfermo en el sitio de Chulucanas, fue avisado por su hermano Mariano Salguero a la que se sumó otro aviso que obligó ya a que JS Palomo y Domingo Campos partieran asustados rumbo a Querecotillo (f.16).

También oyó decir que en este viaje y cuando pasaban de la "Hacienda Nueva» a Querecotillo se encontraron Palomo, «El Flaco» y Gregorio que estaban siendo perseguidos por un tropel de gente que sumaban un poco más de 200 hombres y que ante este peligro los mencionados apuraron sus caballos y se dirigieron hacia Chocan para de allí dirigirse nuevamente a Somate y lograr esconderse. Después y esta vez con las noticias que recibieron de los amigos pudieron escaparse hacia otros montes vecinos. Ellos recordaban ese día porque fueron primero a comer unas sandias coloradas a la chacra de Andrés Camacho y cargaban sobre sus hombros dos escopetas y un esmeril que usados podían arrear a treinta hombres, además de un par de pistolas y un sable que podían haber usado para su defensa, pero el ruido que hizo la tropa con sus voces y los disparos que realizaban al cielo era tan grande que el miedo los asustó.

En adelante y descartando las falsas noticias que les hacían llegar, durante el tiempo de ocho días estuvieron andando ocultos por los cerros de Suipirá y anduvieron cada uno por su lado y dispersos con la finalidad de evitar que los capturen. En los caminos que recorrían recibían las noticias de los amigos arrieros y pudieron así eludir a la tropa del rey y del hacendado. Días después retornaron nuevamente a Chulucanas, a la casa de Isidro Sato y preguntaron si este había recogido un caballo «lobo" de Palomo; de allí por la noche optaron por dormir en la ladera de un cerro para en la madrugada bajar a un monte vecino. Al día siguiente ocurrió que el negro JM Izquierdo había sido apresado por Isidro Sata, su sobrino, uno de sus yernos y «El Flaco». Sobre este acontecimiento 
muchos presumen que JS Palomo tomó un acuerdo con Isidro Sata para apresarlo ya que el declarante le había manifestado su intención de viajar pronto a la ciudad de Lima.

Otro personaje que va a ser llamado para declarar es Sebastián Garrido, edad 58 años, vecino y comerciante, dueño de la hacienda Culqui, Ayabaca. Las autoridades guardan la sospecha de que este forma parte de la cuadrilla de Palomo. Sin embargo, Garrido retoma lo anteriormente presentado. Explica que en 18.10.1815 llegó a su hacienda Salvador de la Cruz con el pretexto de buscar que comer pues los peones que trabajaban en las vegas se habían comido su fiambre. Y al no ser atendido Salvador empezó a buscarlo en otras casas para finalmente lograr que lo atendiera don Mariano Saavedra. Terminado su «hambre» Cruz regresó al sitio de Tierra Colorada. Similar acción se repitió al día siguiente y esta vez se presentó Palomo pidiendo también comida. Ambos traban una conversación animada y es en esa oportunidad que Palomo le cuenta que permaneciendo en el puerto de Tumbes ocurrió que su mujer se había fugado con otro hombre del pueblo de "La Huaca» y que le dejó a su poder dos muchachitos para irse hacia Ayabaca. Así, en plena conversación Palomo le pidió un pedazo de azúcar para tomar un poco de agua hervida. Hasta ese momento el ambiente era de mucha alegría y generosidad. Para la tarde llegó entonces su mayordomo Manuel Guarnizo y un carpintero llamado Juan Barrera y ambos pasan a conversar con Palomo las novedades del vecindario. De igual forma también JM Izquierdo ingresa a la cocina a buscar un poco de agua y fue en ese momento que aprovechó para apresar a un zambo llamado Miguel y ve como también Paloma se movilizó para apresar a Guarnizo y al carpintero. En otra parte vecina el tal Vargas atacó y lanzó a Garrido varios sablazos y gritos, Guarnizo ofreció poca resistencia y se defiende cuando observa que Palomo está herido.

La confusión de esta pelea provocó que casi todos buscaran a recorrer la casa y Vargas y "Chapeta» se dedicaran a registrar un cuarto buscando el dinero y las joyas de plata. Garrido ya no puede reaccionar a este ataque pues le había caído un sablazo en la cabeza. Lo mismo le ocurrió a un indio del pueblo de Pillo quien llegó de manera imprevista. Esta vez sorteando las dificultades lograron amarrar a dos criados y al hijo de don Montano Román. Luego prenden varias velas y mecheros para empezar a recorrer los cuartos buscando los baúles con mucho apuro; y en un cuarto pequeño encuentra a una mujer con su hijo en los brazos, y es así como le piden la llave de los baúles y aprovecha Garrido para decirles que la llave se encuentra debajo de un colchón. Abiertos los baúles Palomo tomará dos pistolas y Vargas un reloj. JM Izquierdo, Chapeta y Vargas se dedicaron a destrozar los baúles y solo lograron tomar una talega que contenía 240 pesos, otro de 1,700 pesos en plata y oro acuñado, una canastilla de alhajas de oro, un cabrestillo de 160 castellanos de oro en pasta y 14 castellanos de oro el polvo. A todo esto, se agregaron dos pares de charretelas, un par de hebillas grandes, un «mecherito «de oro y otro de plata, un «atriaguero", tres pares de botones de camisa, 24 perlas nuevas, un prendedor, una gargantilla de topacios enjoyados y una caravana (f.34v).

Avanzando en esta operación y en un descuido el negro JM Izquierdo le aplicó una patada en el estómago al declarante y lo dejó casi sin aire; después junto con Chapeta le preguntaron acerca de donde se guardaba la otra cantidad de dinero en moneda plata que tenía y al no encontrar una respuesta convincente lo encerraron en un cepo. De esta forma, a lo enumerado se sumarán otros bienes que se llevaron como una vasenica, una palangana, una tembladera, tres platos, dos cubiertos, un jarro, una chilena y un par de espuelas de plata. Finalmente, y al poco rato se escuchó un ruido fuerte como si llegara una tropa de caballos y asustados cargando lo sustraído todos los asaltantes se fueron por unas quebradas. Esa vez quien llegó a la casa-hacienda fue el mayordomo de la hacienda Culqui. Y al revisar los cuartos al día siguiente se dieron cuenta que entre sus papeles que guardaba faltaban unos expedientes judiciales que siguieron unos indios contra Isidro Ortiz y que no fue cierto que se llevaron los títulos de propiedad de su hacienda (f.35v).

Finalmente se presentó a declarar Josefa Palacios, edad 35 ańos, mujer negra y esclava de don Gregorio Palacios, su amo ya finado. Confiesa que ese día como a las once de la noche salió a pasear con Rafaela Moncada, una mujer que ahora se encuentra en Guayaquil, y llegó a la casa don José I. Palacios y este preguntó a gritos de porque estaba abierto el postigo, y fue que sintió la llegada de una tropa compuesta de seis hombres desconocidos que le dijeron que estaban 
haciendo su ronda. Y solo así fue como se pudo recuperar la tranquilidad. ${ }^{11}$

\section{Los resultados militares logrados por Fernández de Paredes y las opciones de juego con la política de un bandolero piurano a comienzos del siglo $\mathrm{XIX}^{12}$}

Lo que sigue en el expediente es un escrito cuyo contenido refleja el orgullo de un terrateniente limeño que ha recibido la designación de comandante militar por el propio virrey Abascal para capturar a un «ladrón famoso» y a su cuadrilla que supuestamente tiene aterrorizado a la ciudad de SM de Piura, a las haciendas de la costa y la sierra y a los campesinos indígenas de los pueblos yungas y serranos. En un oficio escrito con letra palmer se encuentra el siguiente título: «Don Francisco Xavier Fernández de Paredes, comandante del Escuadrón de Dragones del territorio de Amotape, La Chira y Tumbes, por Su Majestad y Juez Pesquisidor por el excelentísimo virrey del reyno contra el ladrón famoso José Sapata (alias) Palomo y cómplices, ladrones famosos (f.157). Julio 8 de 1816».

11 En otra sección de este expediente se encuentra un documento fechado en SM de Piura, en 29.03.1816, en la que Fernández de Paredes resume lo informado por los declarantes y elabora una lista de los testigos presentados:

\begin{tabular}{|l|l|}
\hline N. «El Flaco» & Salvador de la Cruz \\
\hline José Vargas (a) «El Cabezón» & Pedro «Malo» \\
\hline N. «El Manco» & Manuel Palacios \\
\hline José María Vásquez (a) «Chapeta» & Miguel Meca (a) «El Viejo». \\
\hline Hombres con indicios & \\
\hline Manuel A. Sánchez & Isidro Ortiz \\
\hline Pablo Jiménez & $\begin{array}{l}\text { N. El Nato de las Panchillas } \\
\text { (f.43). }\end{array}$ \\
\hline
\end{tabular}

En SM de Piura, en 29.03.816, Fernández de Paredes ordenó que los mencionados en esta lista no pudieran salir y que consideren la «ciudad por cárcel». Concluye señalando esta vez que Palomo todavía está libre y pide que todos los reos sean nuevamente notificados con un escrito.

12 La coyuntura política virreinal y local que presenta Elizabeth Hernández (2013) es contraria a la que se presenta en esta investigación. La elite de Piura vive ya una crisis política y uno de sus miembros, don Francisco Xavier Fernández de Paredes simboliza la preocupación de una facción que ingresa a la política en tiempos de profunda influencia de la Constitución de Cádiz y de arrebatos asesinos e histéricos de un virrey que no puede contener la insurgencia popular y campesina en la provincia de Piura. Para una biografía política de Fernández de Paredes puede consultarse Elizabeth Hernández 2007: 361-391.
Para la mitad del año de 1816 el subdelegado y su proceso judicial ha podido percatarse del funcionamiento de dos movimientos sociales todavía no articulados; el primero es el de los cimarrones salteadores y de otro lado, la cuadrilla de José Sapata (a) Palomo. El primero está compuesto por negros, zambos y mulatos que resisten a la explotación de la esclavitud y que guardados en la real cárcel de Piura o en los calabozos construidos en las casas-tinas de los hacendados, terminan casi siempre fugándose; el segundo, es la lista extensa de acusados y guardados en la cárcel por la sospecha de formar parte de la cuadrilla de Palomo y/o de estar practicando actividades que de una u otra forma le sirven a la cuadrilla para ejecutar sus acciones dentro y fuera de la ciudad y haciendas. Lo singular y que caracteriza a este segundo grupo social es que la mayoría son milicianos urbanos y rurales que han sido formados militarmente a comienzos del siglo xix y que la difícil vida política que viven los pueblos y los labradores de la tierra con la llegada de las leyes gaditanas parece que este acto judicial es solo un arma de represión a los que no marchan junto a la voluntad de los grandes hacendados y han optado por refugiarse de manera dispersa en los montes y bosques de Querecotillo, un «palenque» que les sirvió de refugio para poder sobrevivir con el trabajo de la tierra y el tráfico mercantil local e interregional (César Espinoza 2019).

Fernández de Paredes intensificó en adelante sus acciones armadas y judiciales para criminalizar a la cuadrilla de Palomo y también a los cimarrones salteadores, como individuos o grupos. Las autoridades municipales y el Intendente de Trujillo lo presionan transitándose de lo delincuencial hacia la represión política por el contexto de guerra civil que vivía el virreinato del Perú (Juan Luis de Ossa 2016 y Heraclio Bonilla 2008).

En efecto, Fernández de Paredes, desde su mansión en la hacienda de Tangarará, en 16.03.1816, ordena a don Tomás Vega para que proceda a capturar a Salvador de la Cruz, Mariano Salguero, Miguel Meca (a) «El Viejo» y a Juana Niño. Y que también se realice el embargo de los bienes que posean (f. 118).

De esta forma en un escrito que señala a un sitio y pueblo vecino llamado "El Salitral», en 26.03.1816, se realizó el inventario de los bienes de Salvador de la Cruz, un personaje ubicado en el segundo grupo mencionado arriba: 


\begin{tabular}{|l|l|}
\hline \multicolumn{1}{|c|}{$\begin{array}{c}\text { GANADO GRANDE Y } \\
\text { CHICO }\end{array}$} & \multicolumn{1}{c|}{$\begin{array}{c}\text { GRANOS, VEGETALES Y } \\
\text { OTROS }\end{array}$} \\
\hline 6 bestias mulares & $\begin{array}{l}2 \text { caballo de silla, 1 yegua } \\
\text { casecorba y 1 potranca } \\
\text { chúcara }\end{array}$ \\
\hline 1 burro manso aguatero & $\begin{array}{l}2 \text { costales de garbanzos que } \\
\text { suman } 16 \text { arrobas }\end{array}$ \\
\hline 10 cerdos chicos y grandes & $\begin{array}{l}2 \text { lampas usadas y un hacha } \\
\text { usado }\end{array}$ \\
\hline & $\begin{array}{l}\text { Una caja de madera con } \\
\text { chapa y llave de fierro }\end{array}$ \\
\hline & 1 batea de madera \\
\hline & 1 arroba de algodones \\
\hline & $\begin{array}{l}3 / 4 \text { cargas de maíz en mazorcas } \\
\text { (f.119-119v) }\end{array}$ \\
\hline
\end{tabular}

En 27.03.1816, don Tomás de la Vega informó a Fernández de Paredes sobre los resultados del embargo de bienes. Señala que Salvador de la Cruz había ocultado la mayoría de sus pertenencias ya que al interior de su casa no encontró «ni un pañuelo viejo» (f.120). Agrega que se le ha informado que este miliciano y labrador de la tierra fue avisado y que aprovechando la noche pudo sacar las escopetas, los aperos, las monturas, los frenos, las espuelas, las jáquimas y otros. Concluye señalando que los maíces-algodones y las bestias registradas solo representan una pequeña parte de lo que posee un pequeño labrador y ex miliciano campesino.

El comandante Fernández de Paredes quiere más pruebas y en 22.03.1816, ordena que Matías Mesones pase a "Tierra Colorada», Ayabaca, para ejecutar similares acciones represivas y de embargo (f.121).

Finalmente, en su desesperación para lograr la captura de Palomo ordena traer a su actual amante, María Dolores Campos, natural de Querecotillo para que conversando y pidiendo responda a un nuevo cuestionario de preguntas se logre disponer de algún hilo o huella del lugar en la que se encuentra escondido José Sapata. Campos elude la mayoría de las preguntas y se concentra en un asunto distractivo. Ella le cuenta que don Francisco Gallo, por recomendación que le hizo Palomo, recibió un pequeńo cofre que contenía las joyas siguientes provocando la admiración del comandante y hacendado:

\begin{tabular}{|l|l|}
\hline \multicolumn{1}{|c|}{ Joyas y alhajas } & \multicolumn{1}{c|}{ Otras joyas mencionadas } \\
\hline Alhajas de oro y dos cadenas & Un par de caravanas \\
\hline $\begin{array}{l}2 \text { pajuelos y un ramo de 13 } \\
\text { tembleques emperlados }\end{array}$ & $\begin{array}{l}\text { Un par de faluchos con } \\
\text { peineta grande }\end{array}$ \\
\hline 2 sortijas con piedras del ynga & $\begin{array}{l}\text { Un crucero empedrado y } \\
\text { piedras del Ynga }\end{array}$ \\
\hline 1 tembleque emperlado & $\begin{array}{l}\text { Un prendedor con su perla } \\
\text { grande }\end{array}$ \\
\hline $\begin{array}{l}1 \text { par de estriberas de plata } \\
\text { con su correa y canutos que } \\
\text { ahora lo tiene Palomo }\end{array}$ & $\begin{array}{l}\text { (ver otro listado de joyas en fs. } \\
\text { 123-128). }\end{array}$ \\
\hline
\end{tabular}

Otro asunto que ocupa el tiempo de la entrevista es lo que escuchó decir que Isidro Ortiz vendió a Sebastián Garrido la hacienda de Pillo, en Culqui, y que Garrido estaba incomodo por el número de ganado que se sacaba y que reunidos ambos finalmente acordaron la entrega de 65 cargas de trigo y 20 cabezas de ganado por la transacción realizada. El asunto de fondo es que por las desavenencias existentes entre ambos no se pudo cobrar ciertas deudas pendientes a los indios del lugar.

Ya con la posesión de esta información, en 15.06.1816, Fernández de Paredes avisa que ya llegó a la ciudad de Piura y que, preguntando en esta ocasión por Isidro Ortiz, se le avisó que este aprovechó para ausentarse a Pelingará (f.150).

Finalmente, don José Garzón señala que en la puerta del Cabildo y por la voz del pregonero Antonio Ramos se informó a todo el vecindario de las noticias que han llegado de Lima y en particular el encargo que le ha otorgado el virrey Abascal a don Francisco Xavier Fernández de Paredes, comandante del Escuadrón de Dragones del territorio de Amotape, La Chira y Tumbes, por Su Majestad Fernando VII.

\section{La resistencia sociopolítica a la dominación de Abascal por los milicianos negros, cimarrones salteadores y el bandolerismo rural en el valle de $\mathrm{La}$ Chira, Querecotillo}

Este trabajo de investigación se concentra en una coyuntura singular, la restauración de Fernando VII y los finales del gobierno de Abascal y comienzos de 
Pezuela en un espacio regional, Piura y el valle de La Chira, entre 1814 y $1818 .{ }^{13}$

En la sección anterior se presentó una primera versión sobre la historia de vida de un hombre del campo, desertor de las milicias reales y de su banda que actúa dentro de la provincia de Piura y fuera de ella hasta extenderse a la ciudad de Lima. Es una cuadrilla de negros esclavos y libertos liderado por José Sapata (a) Palomo. Un labrador y miliciano que despliega su fuerza armada a favor y en contra de un gran terrateniente y militar realista, don Francisco Xavier Fernández de Paredes, quien llegó a Piura para administrar la herencia territorial de una familia noble de la sociedad limeña. ${ }^{14}$

Palomo es un labrador y pequeño comerciante que se moviliza entre la sierra de Loja y los pueblos de Olmos y Motupe por el norte para refugiarse temporalmente en el territorio piedemonte andino de Yapatera y Morropón la otra gran hacienda que posee Fernández de Paredes.

Lo interesante de esta historia política es el surgimiento de una población que empieza a asentarse en ambas haciendas de mayoría poblacional negra, esclava y liberta. En Tangarará, ubicada en el valle de La Chira cuyo territorio mira hacia el mar y Morropón ubicado en el piedemonte andino de los Andes se han concentrado grupos de labradores de la tierra y de trabajadores ganaderos que han adscrito a otros pobladores para organizar una especie de "palenques» hacia las cuales se dirigen una población rural que vivía de la delincuencia, del contrabando y los que no tienen tierra ni trabajo alguno (Tardieu 2018 y 2004).

Los Borbones buscaron nuclearlos y centralizarlos en doctrinas e imponerles curas y autoridades menores para controlarlos. Los funcionarios de Martínez Compañón visibilizaron a esta población que vivía dispersa y aglutinaba a gente de la sierra y también a la yunga procedente de Catacaos y Lambayeque. Con el pretexto de la evangelización los concentraron alrededor de una capilla y les otorgaron una porción de tierra que vía un contrato oral pudieron otorgar-

13 En la primera parte de este articulo trabajamos los episodios y la reconstrucción de un listado preliminar de los actores participantes correspondientes a los ańos 1815-1816 para luego ubicarlos en la dinámica de la coyuntura regional y virreinal de los ańos 1817-1820.

Sobre la conducta social y política de los bandoleros puede consultarse a Eric Hobsbawm (1959 y 1969), a Paul Vanderwood (1984 y 1986) y a Jean-Pierre Tardieu (2004 y 2017). lo los terratenientes con la finalidad de minimizar la epidemia del bandolerismo rural (Lorenzo Huertas 1996: 91-124).

En suma, desde 1784 se impondrá en este valle la vigilancia de un cura, de los mayordomos de la hacienda y de los encargados del corregidor provincial. Pero todo este conjunto de reformas va a quedar en el papel porque la población rural pobre y sin tierras migra y se asienta al interior del valle de La Chira que tiene agua durante todo el año y las tierras de orilla empezarán a ser orientadas al cultivo del algodón y los espacios de quebrada habilitadas a una diversidad de potreros para el engorde del ganado caprino y vacuno cuyas materias primas van a abastecer a las fábricas y tinas de jabón y de cordobanes en el propio río de La Chira y en las vecindades de la ciudad de SM de Piura.

Las campañas contra el bandolerismo fracasan y nuevos pueblos y asentamientos rurales se dispersan al interior y en las fronteras de las haciendas del valle de La Chira y Morropón-Yapatera-Salitral, un espacio fronterizo de entrada y salida con los pueblos indígenas de Guancabamba y Guarmaca (César Espinoza 2010: 223-244).

Hacia estos pueblos rurales informales se movilizan los mayordomos, los alcaldes y regidores, los jueces y defensores de indios, pero también las autoridades que recaudan los tributos y los diezmos. Los curas también ingresan a este mundo de negocios alquilando las manadas de ganado caprino e imponiendo censos y capellanías para vivir de sus rentas anuales.

Es contra este mundo rutinario que Palomo y un grupo de negros va a resistir realizando operaciones y asaltos a las casas-haciendas de algunos hacendados, pero también invadiendo y saqueando las casas de algunas familias ricas de la ciudad de SM de Piura. Palomo transita de personaje marginal a la figura de un famoso bandolero provincial que va a convulsionar este territorio porque su actuación y protagonismo no se reduce a lo delincuencial sino al mundo de la política en la que estaban envueltos los dueños de la tierra y comerciantes como Fernández de Paredes y los Seminario en Piura. Muy fácil sería ubicarlo como un bandido más o un personaje marginal de la política de su tiempo como lo señalaron de manera discriminatoria Enrique López Albújar, Estuardo Cornejo o Miguel Gutiérrez, y escritores y analistas del siglo xx. Este trabajo parte de un examen docu- 
mental y el análisis de una variedad de episodios en la vida no solo de José Sapata (a) Palomo sino también de algunos de sus acompañantes que se aventuraron en vivir y recorrer dos grandes ciudades costeñas, Lima y Piura, para encontrarle un sentido a sus vidas y ubicarse en posiciones que la guerra y la crisis de la monarquía los obligaba a apostar. Los funcionarios del gobierno virreinal los vieron como gente peligrosa que podían transitar de salteadores y desertores a bandas y líderes que podían contribuir a ser agentes perturbadores del orden virreinal, o sea transitar y convertirse en parte de una plebe politizada que podían utilizar los «revolucionarios» que ya se expandían por el sur desde Buenos Aires y por el norte en Angostura y Guayaquil (Gabriel Di Meglio 2007 y 2013; Cristóbal Aljovín y Marcel Velázquez 2017).

El examen del tiempo político de Palomo es muy interesante porque permite observar el movimiento de los cargos políticos y militares entre los gobiernos de Abascal y Pezuela. Es al interior de esta coyuntura política que se examina las acciones que despliega Palomo con un grupo de negros esclavos y libertos milicianos y desertores que han optado por vivir de su trabajo en la tierra y el pequeño comercio y eventualmente de algunas actividades delictivas para poder sobrevivir al interior de un pueblo en formación como Querecotillo y el gran latifundio de Tangarará.

Palomo representa a un sector social llamado despectivamente de plebeyos frente a otro grupo social que se autoidentifica como parte de la nobleza española, aunque la mayoría está compuesta de gente criolla o sea nacidos en la provincia de Piura, pero portadores de una mentalidad monárquica y de valores y una mentalidad proesclavista.

Los episodios de la vida de Palomo son peculiares pues es un hombre que deja Querecotillo a los 16 años para viajar hacia otras ciudades y asentarse en 1814 en la ciudad de Lima. En sus declaraciones se reafirma en lo valioso que tuvo esta experiencia de salir de Piura y vivir con los marinos en el mundo caribeño. Luego en Lima busca vivir de lo poco que tiene, pero fracasa porque el clima represivo contra los que apostaron por el mundo gaditano lo oprime y tiene que sobrevivir en la periferia de la ciudad de los reyes hasta formar parte de las bandas que azotan la vida de marqueses y condes y vivir clandestinamente en el palenque de Huachipa y los extramuros de la hacienda de La Molina. Es aquí donde nuclea una pequeña banda de negros y mestizos que utiliza para realizar operaciones que le dan fama de bandolero que persigue en persona el virrey Abascal. Asaltar a marqueses viajeros y a una recua de arrieros y soldados que transportaban oro y plata procedente de la Casa de la Moneda lo convertirá en un personaje rico y festivo que terminará finalmente en la Real Cárcel de Lima. Lugar del cual se fugará dos veces y terminará por regresar a su pueblo natal Querecotillo, Piura, para intentar readaptarse a la vida cotidiana de un labrador del campo y las actividades mercantiles locales. Pero es poco lo que aquí puede conseguir porque como líder de una banda y de compañeros negros que viven del robo y el asalto pronto está envuelto en las tensiones y pugnas que expresan las diversas facciones de la elite dominante de Piura. De tal forma que si su persona y sus compañeros fueron la fuerza que apoyaron a Fernández de Paredes para afirmarse como el comandante del batallón de los Dragones de Amotape, al poco tiempo esta autoridades militar recibirá la orden de perseguir y eliminar a Palomo porque para Abascal y las fuerzas políticas de Lima, este sujeto se había vuelto peligroso en el panorama de la guerra que vivía España contra los amigos insurgentes y patriotas que empezaban a avanzar por Buenos Aires en el sur y Guayaquil por el norte de los Andes.

Otro asunto curioso y que llama la atención es que Palomo regresa a Querecotillo cuando la elite provincial de Piura liquidó el proyecto de formar un nuevo Cabildo Constitucional (1813) en el pueblo de La Punta de Tillopaira apoyado por el virrey Abascal manteniéndose derrotado temporalmente este grupo emergente en el valle de La Chira que tiempo después lograría conquistar la categoría de villa, distrito y provincia a lo que ahora se llama Sullana. ${ }^{15}$

En el expediente judicial revisado se oculta esta operación contrainsurgente a la que actuaron aliados Fernández de Paredes, el clan de los Seminario y el cura vicario Tomás Dieguez. Lo que empieza a visibilizarse entre 1815 y 1819 es la actuación política y militar de un grupo de hacendados y comerciantes criollos que trabajan como aliados políticos de Abascal y Pezuela para contener a las facciones políticas rivales y usar como distracción la actuación y dinámica de lo que ahora empieza a criminalizar-

15 Este acontecimiento político ha sido trabajado de manera parcial por Miguel A. Seminario (1994) y Elizabeth Hernández (2008). 
se como bandas de salteadores, vagos, criminales y rateros. Para completar, esta región será militarizada creándose primero las milicias, luego los batallones de Dragones y la construcción de los fuertes marítimos y cuarteles con el apoyo de las elites y masas comuneras indígenas. ${ }^{16}$

Podemos postular algunas características o elementos que definen a estas asociaciones llamadas banda, cuadrillas o salteadores rurales en Piura. En general, estas emergen con mayor fuerza después de la experiencia del gobierno gaditano. Esta liderado por un hombre y compañeros de origen africano. La mayoría son ex milicianos y desertores campesinos procedentes del valle de La Chira. El miedo que sienten los comandantes militares y el subdelegado de Piura es al movimiento incontenible de su líder Palomo y un grupo que lo rodea procedentes de Lima y Lambayeque. Son gente que manejan las armas de fuego, viajeros permanentes, amantes de mujeres bellas y sin miedo al combate cuerpo a cuerpo. Hombres de caminos que usan la razón y la pasión para vivir, gente que tejen sus redes de amistades y compadres para disponer de información local, virreinal e internacional.

Palomo dirige una pequeña banda de no más de diez integrantes formados con negros, mulatos y zambos que han nacido en la campiña de Querecotillo, Chocan y Tangarará. La mayoría son ex milicianos, labradores de la tierra y expertos en el manejo del trabuco y la pistola.

Muchos de los que viven en Querecotillo han participado en el proyecto de fundar el pueblo La Punta y el Cabildo Constitucional (1813) viviendo resentidos de la fuerza militar y judicial impuesta desde la vieja ciudad de San Miguel de Piura y los batallones militares enviados por Abascal. Son gente opositora al proyecto centralista de Fernández de Paredes, los Seminario y el cura-vicario Tomás Dieguez. Ellos saben que esta derrota es temporal porque la pequeña elite de labradores y propietarios campesinos de $\mathrm{La}$ Punta había sido disuelta y perseguida bajo la acusación de ser enemigos de Fernando VII y de España, pero esto no liquidó su proyecto de formar un poder local al pie de un valle que después con la llegada de Palomo en 1814 se reiniciará una agitada lucha polí-

16 Sobre la coyuntura política después de 1814 puede revisarse a Scarlett O’Phelan y George Lomné (2013), a Víctor Peralta (2002 y 2008). tica entre las facciones que apoyaban al monárquico Abascal y después al liberal Pezuela en este espacio regional norteño.

Otro elemento que caracteriza a este líder y grupo de gente dedicada al bandidaje es que su área de acciones armadas abarca la propia ciudad de SM de Piura, el camino hacia la ciudad-puerto de Payta, los caminos a la sierra de Ayabaca y los pueblos y médanos desérticos de Olmos y Motupe, vecinos a Lambayeque, otro valle vecino que aglutinaba haciendas y centros poblados de negros esclavos y libertos (Guillermo Figueroa 2014). La mayoría de los negros de la banda son labradores de tierras de chacra y peones de hacienda. Palomo procede de una familia de pequeńos labradores de tierras parcelarias de Querecotillo y Chocan, dedicados también al comercio local y desde 1817 orientado a la habilitación de dinero a pequeños campesinos parcelarios productores de algodón y de engorde de ganado caprino, vacuno y mular. No es un terrateniente, oficial militar o comerciante exportador. Lo que si insiste y recalca en sus declaraciones es que fue miliciano al servicio del rey de España y que tuvo que desertar después de 1814 e ingresar al mundo de la gente que no tiene trabajo y vive de la pobreza y la vagancia cuestionando y resistiendo el mundo social que le quisieron imponer.

Los funcionarios virreinales revisores de los testimonios judiciales en Lima no aceptan estas declaraciones y encuentran que los escritos presentados por el subdelegado y sus abogados tienen solo un sentido y contenidos político que los acercan a los que llaman en este tiempo «revolucionarios» o insurgentes, para los que sirven a Abascal o Pezuela nadie podía mantenerse en el centro o posiciones neutrales. Motivo por el cual en Lima se desechan los procesos judiciales utilizados y llaman la atención a los subdelegados, fiscales y abogados por organizar sumarios que no ofrecen evidencias de lo ordenado por los superiores, es decir, ubicar y liquidar a la plaga de gente que estaba perturbando el orden público virreinal en esos ańos y en estos territorios vecinos a Guayaquil y a Quito.

En el examen de este acontecimiento se puede encontrar un fuerte contraste entre la imagen que quieren presentar las autoridades provinciales de Piura con lo que busca el poder central virreinal, es decir, los enemigos de la patria espańola o sea los insurgentes. Si los primeros buscan solo presentar acciones 
delincuenciales y asaltos y robos de Palomo y su cuadrilla de negros esclavos y libertos. Los funcionarios de la Real Audiencia de Lima lo que buscan y desean es encontrar evidencias de enemigos de España, para ellos Palomo viajó de Lima a Piura no solo para robar gallinas sino para informar y coordinar actividades con gente que está deteriorando la maquinaria de gobierno monárquico virreinal. Es por este motivo que devuelven los expedientes desde Lima, en reiteradas oportunidades, para que en Piura se cumpla con los careos y la aplicación de nuevos cuestionarios que ayuden a ubicar y conseguir información de los enemigos de España pues Piura había sido militarizada y se tenía noticias de que las fuerzas insurgentes avanzaban por la sierra y el mar de Quito y Guayaquil. El asunto se hizo mucho más grave con la noticia de que los portugueses estaban buscando ingresar por las montañas de Moyobamba, Chachapoyas y Jaén de Bracamoros vinculados íntimamente a la ciudad de SM de Piura y la ciudad-puerto de Payta (Waldemar Espinoza 2014).

En efecto, en los expedientes consultados que suman más de 500 folios lo que encontramos es un esfuerzo del subdelegado y de sus asesores legales por ofrecer imágenes con descripciones retrospectivas de Palomo y sus acompańantes. Los escritos y textos que lo acompañan nos permiten seguir una cronología de por donde viajan los comisionados y el número de testigos que se presentan para recoger una primera respuesta a los cuestionarios. Se trata entonces de la producción de evidencias documentales que van a llegar a ser leídas por las autoridades judiciales de la Real Audiencia y que van a ser rechazadas y los expedientes a viajar de regreso a la ciudad de SM de Piura. En medio de este accionar de Palomo y su cuadrilla de negros libertos y esclavos se observa el despliegue de la vida de otros hacendados y militares que buscaran defenderse de las acusaciones del subdelegados de turno.

En este esfuerzo por el trabajo retrospectivo es decir de reconstruir la historia de vida de Palomo, se encuentra un expediente de las actividades de este personaje a partir de 1804 , un tiempo en la que la provincia de Piura va a ser gobernado por un subdelegado apurado en formar milicianos que sirvan para la defensa de una posible invasión marítima británica por Tumbes y Payta. En esta sección se puede encontrar noticias sobre el movimiento de las patrullas, las comunicaciones entre el subdelegado y las autoridades de los indígenas y otras noticias que conciernen a las actividades de bandidaje practica por José Sapata (a) Palomo al interior del valle de La Chira. ${ }^{17}$

\section{Las bandas de cuatreros y salteadores como problema histórico y político}

Los virreyes, los subdelegados y los abogados de la época elaboran un lenguaje para caracterizar a la gente subordinada, a los individuos y a los grupos que están obligados a obedecer y a reconocer la autoridad y la dominación de los que mandan desde el Estado virreinal. ${ }^{18}$

Lo singular del espacio social del valle de La Chira y Querecotillo es que se trata de una población multiétnica y con una mayoritaria vecindad de origen africano. Son labradores de la tierra y milicianos negros, zambos y mulatos, que viven en este microespacio territorial en la condición de libertos y de esclavos, gente subordinada a un hacendado, comerciante o traficante de esclavos en la ciudad de SM de Piura.

La percepción y registro de la elite de una provincia busca mediante el lenguaje diferenciarlo e incrustar a los sectores sociales subordinados o subalternos en una posición jerárquica de la dominación. Si en el aparato administrativo a la población de origen africano se les clasificaba como negros, esclavos o libertos, ahora empieza a utilizarse otra categoría clasificatoria y discriminatoria, los Pardos. Un grupo social que está informado como en las Cortes de Cádiz se les recorta los derechos civiles y la participación en los sistemas de representación y del sistema electoral; los negros y mestizos con sangre africana no son ciudadanos sino parte de los grupos de castas que forman parte de una sociedad local o regional, es decir, "gente bárbara» y sin derechos políticos.

Los abogados todavía los presentan como semisalvajes propensos a las tareas manuales y dedicados

17 Archivo Regional de Piura. 1804. Intendencia, legajo 62, expediente 1208. Causa criminal contra Juan José Zapata (a) Palomo, seguido por el subdelegado Pablo Patrón de Arnao.

18 Veamos una pequeña lista todavía incompleta para categorizar a los que encuentran fuera de la ley: malhechores, hombres vagos, de licenciosa vida, borrachos y rateros, hombres mal inclinados, ladrón, ratero de gallinas, gente bulliciosa y lleno de discordia, hombres de genio díscolo, vago sin trabajo, hombre sin oficio, vago y ladrón de ganados, sin oficio y malas costumbres, mal entretenido, ladrón y ratero consumado, practica la cuatrería en los campos, bandido, rey del monte y famoso ladrón. 
al trabajo en la tierra y en las campińas ganaderas. Con los Borbones se los selecciona para formar parte de una fuerza militar para resguardar y garantizar la seguridad no solo interna sino como una fuerza auxiliar para enfrentar a los enemigos de la monarquía hispana. Los libertos de Piura van a incorporarse a los escuadrones de los Dragones, por ejemplo, y casi todos los varones son obligados a formar parte de las milicias urbanas y rurales en la provincia de Piura. Unos van a formar parte de los pelotones de infantería, otros en la caballería y unos pocos al manejo de la artillería.

El subdelegado y los alcaldes de cabildo prestan mucha atención en registrar a los líderes y miembros de estas agrupaciones según las castas y etnias a las que pertenecían. Negro, zambo, mulato, zambillo, zamba, mulatilla, etc. Otro dato singular que acompañan a sus nombres y apellidos son los apelativos con los que los identifican: «Palomo», "Cruel», «Siete Cintas», "Ñato», "Siete Cintas», "Chancaca», etc. Este énfasis «étnico» y los apelativos servirán para registrarlos como parte de lo que en este tiempo se llamaba la «plebe» frente al grupo dominante que se autorepresentaba como parte de la nobleza virreinal.

Es de advertir también que en los escritos y memoriales es muy poco todavía el uso de conceptos también discriminatorios como la de "serrano" para inferiorizar a los sujetos que han nacido y vivido en la sierra o quebradas cordilleranas. Asunto que se presentaba no solo entre la gente del común sino también entre aquellos que poseían títulos profesionales o grados militares.

Estos elementos nos sirven para comprender el sentido que ofrece la lectura de los escritos en la que se registran a Palomo y sus compañeros como gente criminalizada y violadora de las leyes reales. Llamarlos ladrones, salteadores, rateros, vagos, ociosos, gente de mal vivir, etc., reducía y limitaba el contenido de sus acciones cotidianas, individuales o como grupo social de gente que se movilizaba a caballo, que portaba su trabuco y su pistola, de individuos que armados de valor y mucha pasión se enfrentaban a las patrullas virreinales o a los hacendados que los perseguían, y de sujetos que luego de largas y prolongadas jornadas de viaje por cordilleras y desiertos usaban la violencia de sus voces y armas de fuego para apropiarse de lo que podían encontrar en una casa-hacienda o una mansión señorial en la ciudad de SM de Piura. Esta agrupación de gentes de origen africana y mestiza constituye entonces una fuerza social que violentaba las leyes y decretos virreinales y se enfrentaba a las tropas de gobierno y a la gente aliada al virrey Abascal y Pezuela.

Este asunto de la conceptualización también se ha trabajado desde las ciencias sociales y la historiografía nacional. Para la historia social de Piura en el siglo XIX es muy poco lo trabajado. Diez Hurtado es un antropólogo que ha reconstruido la historia política de los pueblos y las comunidades indígenas de la sierra. El tema de los bandidos no es un tema central para sus estudios a pesar de que trabajó el asunto de las montoneras antes y después de la guerra con Chile. No existen estudios sistemáticos sobre el bandolerismo para el siglo XVIII y menos para el XIX (Alejandro Diez 1998 y 2012).

Elizabeth Hernández ha privilegiado el estudio de personajes de la elite, civiles, militares y religiosos. Plantea que las facciones de la elite de Piura buscaron solo acomodarse para defender sus intereses materiales y pugnar por mayores espacios en el gobierno de los que sucedieron a San Martin y Bolívar. Nada dice sobre los individuos y las agrupaciones comunitarias e indígenas y menos sobre los afrodescendientes y la fuerza política que construyeron y que les permitieron participar en un acontecimiento político como fue la ruptura con la monarquía española ya sea apoyando inicialmente a Torre Tagle y después a Riva Agüero y a Santa Cruz (Elizabeth Hernández 2011 y 2012).

Lo cierto y ocultado es que el bandolerismo fue epidémico en Piura y que como fuerza social y política quebró el sistema de dominación de los virreyes. Lo singular es que las bandas de salteadores estuvieron integradas por ex milicianos y desertores negros que durante la llamada guerras de la independencia y contra España representaron formas singulares de acción colectiva popular que van a asociarse con las milicias y las tropas militares que van a organizarse con Santa Cruz y Bolívar imponiéndole un sentido a los cambios políticos que se produjeron en la provincia de Piura.

Se trata de contingentes humanos cuyas acciones van a quebrar el sistema de dominación virreinal y colonial pero orientados a las alianzas políticas que entablan los liderazgos representados por los grandes terratenientes de Piura. Podemos postular que si bien 
representaron una fuerza progresiva hasta 1821 posteriormente se orientaron hacia un conservadurismo político pues habían conquistado derechos civiles como el acceso a la tierra y el debilitamiento de la servidumbre. Mas no pudieron avanzar en el proceso de liquidación de la esclavitud bloqueando los procesos de manumisión y de libertad de las poblaciones que vivían en la ciudad y en el campo bajo los lazos de la servidumbre urbana y la esclavitud negra.

Culminado el gobierno de Bolívar y el ingreso a una nueva etapa de anarquía política y de guerra por la frontera con el Ecuador, los negros y las bandas armadas terminaran alineándose al lado de la facción política más fuerte en la provincia de Piura. Los hombres que montan caballos y cargan sus trabucos y pistolas buscaron resolver sus asuntos domésticos y gozar temporalmente de las innovaciones políticas y militares que se presentaron en la esfera política sin trazar ningún tipo de vinculación política con otras agrupaciones o liderazgos de los terratenientes hasta la segunda mitad del siglo XIX.

Durante la guerra contra Espańa empieza a renovarse el vocabulario político y al lado de categorías como bandolerismo y bandidaje empieza a difundirse el concepto de montonera y de guerrillas rurales (Fradkin 2005).

Durante el tiempo gaditano empieza a usarse por los abogados y funcionarios liberales el concepto de montonera con un contenido político específico para diferenciarse de la palabra bandidismo o bandolerismo que criminalizaba y presentaba a sus miembros como delincuentes y gente de mal vivir. Desde el Río de la Plata se expandió su uso y forma parte del lenguaje ya jurídico y político para categorizar a los movimientos rebeldes e insurgentes que cuestionaban el gobierno autoritario del virrey don Fernando de Abascal.

El fenómeno social del bandolerismo o cuatrerismo va a ser entendida de manera limitaba ya que se recortaba las acciones de los miembros participantes solo al robo, al asesinato, al asalto y a la creación de estados de pánico y de miedo de los habitantes de las ciudades, pueblos, haciendas y comunidades rurales. Los líderes y miembros serán calificados de gente ociosa, vagabunda, sin valores ni moral, perversos y de instintos asesinos, gente maligna, ladrones y que solo buscan vivir del trabajo ajeno.
Por tanto, el término de bandido o cuatrero empleado por las autoridades virreinales contiene una fuerte carga despectiva y discriminatoria, vinculado a los negros y plebeyos. Los abogados y funcionarios virreinales usaron estos conceptos para presentarlos como gente que violaba las leyes y decretos que garantizan una sociedad racional. Los bandidos y cuatreros son por tanto gente inferior, bárbara gobernada por las pasiones y los bajos instintos cuyas acciones fomentaban una vista social anárquica.

En las declaraciones que recogen los subdelegados y comandantes militares se presenta a Palomo como un líder que ha construido una banda, un grupo criminal unido por lazos de obediencia y de lealtad solo para sustraer bienes ajenos a los ricos del campo y la ciudad.

De esta forma, en los procesos judiciales a los testigos se les impondrá una diversidad de cuestionarios con preguntas manipuladoras a los que están obligados a responder para registrar respuestas parcializadas sobre los comportamientos de un líder y sus dependientes. Se realizan careos entre los participantes para afirmar el caudillaje de Palomo y el seguimiento emotivo de un grupo de negros que lo acompańa desde la ciudad de Lima y de otro grupo de negros milicianos y desertores que se sumaron a la agrupación solo para acciones armadas contra las casas-haciendas.

Una característica que une a la banda de Palomo es que casi todos los integrantes son de oficio milicianos y labradores de la tierra en Querecotillo y alrededores. Se trata entonces de gente disciplinada a la obediencia ya sea en los cuarteles y trabajos de patrullaje, pero también a las relaciones que deben existir entre los peones y los amos y dueńos y conductores de la tierra y los potreros rurales.

La expresión de este tipo de educación y de cultura rural permitirá que Palomo se imponga como un líder de una banda de gente que estará disponible para actuar y saciar sus demandas domésticas, pero también para asumir encargos políticos como la solicitada por Fernández de Paredes, dueño del latifundio de Tangarará, que requirió de su presencia y servicios para que los vecinos y miembros del escuadrón de Dragones de Amotape lo acepten como el nuevo responsable y jefe militar del valle de La Chira en 1816.

Esta última acción de Palomo aliado al señor de la tierra y comandante militar de La Chira nos permite 
señalar que las acciones de estos líderes en la práctica social no pueden ser vistas de manera reduccionista, o sea a los actos criminales y de bandidaje, sino que las acciones de estos individuos y grupos deben ser examinados como parte de la dinámica del poder y al carácter político de la dominación que imponía el virrey Pezuela y el subdelegado José Clemente Merino. A todo esto, también se encuentra documentada su vinculación e interacción con los miembros de las órdenes religiosas que buscaban conservar sus rentas monetarias anuales e informarse de los sentidos que asumían los comportamientos de Palomo y de los miembros de su banda que sabían no estaban solo circunscritos a las acciones delincuenciales.

Ahora bien, lo que puede observarse en las acciones realizadas por Palomo es la obediencia de los subordinados, ya sea negros piuranos o negros limeńos, para realizar los asaltos dentro y fuera de la ciudad. Muchos de los integrantes también han compartido la cárcel en Piura y Lima y han gozado del tiempo de la libertad fugándose con otros presos de las reales cárceles de Piura y Lima.

La empresa de asaltar un contingente militar que vigilaba la conducción de miles de pesos, en oro en polvo y en barras de plata, por un grupo procedente de la Casa de la Moneda de Lima, agitará el alma y el sueño del virrey Abascal en 1814, creciendo la sospecha de que se trataría de gente ligada a los insurgentes que combatía en la ciudad de Lima. Es decir, para Abascal este ataque no solo representa y refleja un acto delincuencial sino que formaría parte de las acciones que realizaban los agentes vinculados a los revolucionarios insurgentes de Buenos Aires que buscaban destruir la dominación del rey Fernando VII. Esto explicaría porque la correspondencia enviada a los subdelegados y comandantes militares de Piura estaban escritos con una consigna urgente: capturar y exterminar a José Sapata (a) Palomo y sus cuatreros salteadores.

Las acciones armadas que despliega Palomo con su contingente armado implican un manejo racional de los comportamientos de las gentes a las que iban a capturar y someter. También supone el conocimiento del territorio, la disposición de la fuerza necesaria en hombres y bestias para movilizarse y dispersarse, y también el uso de las armas de fuego y la violencia contra militares y civiles. Esto puede examinarse al detalle cuando realizan sus campańas y asaltos dentro y fuera de la ciudad de Lima, pues no era igual tomar por asalto y despojar de sus bienes a un noble como el marqués de Villafuerte comparado al despojo de campesinos arrieros de Catacaos.

Lo expuesto nos permite reflexionar que lo que buscaban representar las autoridades como simples bandas de salteadores dedicados al saqueo y al pillaje de gallinas o cabras buscaban en el fondo ocultar el contenido político de las acciones que desplegaba Palomo y su banda desde el valle de La Chira, una campiña y espacio que empezaba a superpoblarse con gente procedente de la costa y de la sierra de Piura.

En efecto, se trata de gente del campo educado en el manejo de las armas y a la disciplina militar, son los milicianos de Amotape, Querecotillo, Chocan, La Chira y Tumbes que estacionalmente se dedican a trabajar la tierra y al negocio de la venta de ganado mayor y menor, pero también a participar de pequeñas agrupaciones o bandas todavía flexibles e inestables que van a transitar de acciones locales a una diversidad de actividades lideradas por Palomo que van a extenderse por el sur hasta Olmos-Motupe, y por el norte hacia Pelingará-Suipirá y la sierra de Loja. En esta movilización de grandes y extensos espacios desérticos y de quebradas estas agrupaciones van a mantener su carácter y composición heterogénea. Así, por ejemplo, José Sapata (a) Palomo transita de Olmos hacia el microvalle de Salitral, un sitio de entrada y de salida hacia los pueblos serranos de Guancabamba y Guarmaca. Aquí llegará incluso a tomar en arriendo pequeńos lotes de tierras para dedicarse a la labranza y a la compra y venta de toda clase de ganado vacuno y mular.

Los labradores campesinos y los colonos mestizos dispondrán de varias formas de acumulación de un capital monetario que les permita subsistir y movilizarse hacia otros espacios como Tambogande, Yapatera y Tangarará. Muchos practican el bandidaje temporalmente y otros se mudan hacia la sierra de Loja y Cuenca para trabajar con el transporte de la cascarilla y los textiles. No es nada raro encontrar a la gente de origen africano vinculado a la práctica del trabajo con la tierra, la ganadería, el bandolerismo y el contrabando del tabaco y los textiles desde y hacia lugares como Payta y Tumbes.

A modo de hipótesis de trabajo planteamos que el bandolerismo practicado por José Sapata (a) Palomo sí tuvo un determinado alineamiento políti- 
co con las facciones dominantes de la elite en la provincia de Piura durante los gobiernos de Abascal y Pezuela. El que iniciara una campaña implacable para su persecución y captura por el virrey Abascal y luego por don Joaquín de Pezuela tiene su sentido político pues después de enero de 1821 los representantes de los grandes terratenientes, don Miguel Gerónimo Seminario y Jayme y don Francisco Xavier Fernández de Paredes, finalmente también apostaran por distintas opciones políticas, afines al monarquismo constitucional de Torre Tagle y San Martin, el primero, y por otra vía republicana y nacionalista liderada por Riva Agüero el segundo. Palomo y su banda de negros milicianos y libertos se movilizaron entre ambas fuerzas que finalmente tomarán el poder político y el gobierno provincial desde enero de 1821.

Palomo y sus milicianos proceden en su mayoría del valle de La Chira. Se trata de una agrupación multiétnica con una población mayoritaria de negros milicianos, fugados o desertores, que temporalmente también formaban parte con sujetos indígenas o blancos pobres y pocos mestizos.

Lo singular de esta banda de Palomo es que casi todos montan caballos o mulas y manejan armas de fuego como el trabuco y la pistola. Se trata de una fuerza de caballería civil con una potencia de fuego que va a provocar mucho miedo entre los habitantes de la ciudad de Piura. Finalmente, agrego un asunto que también pareciera superficial pero que examinando la documentación judicial plantea problemas necesarios de estudiar para conocer la fortaleza y las debilidades de esta agrupación de milicianos liderados por Palomo entre 1814 y 1818. Me refiero a la vida emotiva y erótica de José Sapata que en este lapso va a convivir con dos mujeres, ambas jóvenes, de condición zamba, una procedente de la ciudad de Lima y la segunda, natural del pueblo de Querecotillo. ¿Cuáles fueron las vinculaciones de ambas mujeres con Palomo y la banda de negros libertos y esclavos? ¿solamente el amor y el dinero?

Para concluir, podemos postular la proposición de que la revisión de estos expedientes judiciales nos ha permitido introducirnos en el examen de las prácticas y experiencias políticas de los campesinos afrodescendientes e indígenas que vivían en el valle de La Chira, Querecotillo, Piura. También, mediante el uso de la metodología de la microhistoria buscamos iniciar la indagación de algunos aspectos singulares de las culturas políticas campesinas que se expresaban a través de una variedad de formas de acción y finalmente, iniciar una primera reconstrucción y lectura de las cambiantes relaciones y vinculaciones cotidianas de los individuos y grupos rurales con un aparato estatal virreinal en proceso de descomposición y fractura política.

\section{Referencias bibliográficas}

Aguirre, Carlos y Charles Walker (edits.) (1990). Bandoleros, abigeos y montoneros. Criminalidad y violencia en el Perú. Siglos XVIII-XX. Lima: Instituto de Apoyo Agrario.

Aljovín, Cristóbal y Jacobsen, Nils (2007). Cultura politica en los Andes, 1750-1950. Lima. IFEA - UNMSM.

Aljovín de Losada, Cristóbal y Marcel Velázquez Castro, M. (compiladores) (2017). Las voces de la modernidad Perú, 1750-1870. Lima: Fondo Editorial del Congreso del Perú.

Aldana, Susana (2018). De llave del reino y frontera a límite. Un ensayo sobre la Transversal de Huancabamba y su construcción como región entre dos países BIFEA, № 47 (1), pp. 19-39, Lima, Perú. 2017. Despertar el alma nacional: imágenes de la región y la nación en la construcción de la nación peruana». Tesis Doctor en Historia, UPG de Ciencias Sociales, UNMSM, Lima, Perú. 1988. Empresas coloniales. Las tinas de jabón en Piura. Edic. CIPCA e IFEA, Lima, Perú.

Alva Viale, Harold (2010). Piura. Antología de narrativa contemporánea. Ediciones Altazor, Perú.

Alzamora Lozano, Teodoro (2016). Froilan Alama, amoríos de un bandolero. Casa Nuestra Editores, Trujillo.

Arrelucea Barrantes, Maribel (2018). Sobreviviendo a la esclavitud. Negociación y honor en las practicas cotidianas de los africanos y afrodescendientes. Lima 1750-1820. Lima: IEP.

Baca, Susana; Ricardo Pereira, Francisco Basili (2014). El amargo camino de la caña de azúcar. Asociación Agua e Nieve. Lima.

Bascuñan Añover, Oscar y Jesús-Carlos Urda Lozano (2016). El lugar del bandolero en el conflicto rural. Una aproximación historiográfica desde la obra de Eric Hobsbawm. En: Vinculos de Historia, N5, pp.15-26. Universidad de Castilla-La Mancha, España.

Bonilla, Heraclio (2008). La experiencia del Perú con las juntas y la naturaleza de la participación política de la 
población nativa. En: Ponencia presentada al Panel sobre el Bicentenario de la Independencia organizado por el Comité del Bicentenario "José Manuel Restrepo», en el marco del XIV Congreso Colombiano de Historia, Tunja, del 12 al 15 de agosto de 2008

Castillo, Antolín (2010). Ya vienen los montoneros. Edic. San Marcos, Lima, Perú.

Castillo, Antolín (2012). Repican las campanas. Editorial San Marcos, Lima, Perú.

Castillo R. Leonidas (1977). Los rezagos esclavistas en Piura en el siglo XIX: 1800-1854. Tesis Bachiller en Historia, CCSS, UNMSM, Lima, Perú.

Chiaramonti, Gabriella (2005). Ciudadanía y representación en el Perú (1808-1860). Los itinerarios en la soberanía. Lima, Fondo Editorial UNMSM, SEPS, ONPE. 2007. De marchas y contramarchas: apuntes sobre la institución municipal en el Perú: 1812-1861. En: revista Araucaria, $\mathrm{N}^{\circ} 18$, pp. 150-179. 2004. Los nudos del sufragio: un problema de gobernabilidad republicana. En: Mc Evoy. La experiencia burguesa. Edic. Iberoamericana, Madrid, pp. 284-307.

Del Busto B., José Antonio del (edit.) (2004). Historia de Piura. Piura. Universidad de Piura - Municipalidad provincial de Piura.

Conde Calderón, Jorge (1999). Espacio, sociedad y conflicto en la provincia de Cartagena 1740-1815. Colección de Ciencias Sociales y Económicas Rodrigo Noguera, Barranquilla, Colombia.

Contreras, Carlos y Elizabeth Hernández (edit.) (2017). Historia económica del norte peruano. Señorios, haciendas y minas en el espacio regional. Banco Central de Reserva e Instituto de Estudios Peruanos, Lima, Perú.

Contreras Cruces, Hugo (2006). Las milicias de pardos y morenos libres de Santiago de Chile en el siglo XviII. En: Cuadernos de Historia, Número 25, pp. 93-117. Departamento de Ciencias Históricas, Universidad de Chile, Santiago de Chile. 2011. Artesanos mulatos y soldados beneméritos. El Batallón de Infantes de la Patria en la Guerra de Independencia de Chile, 17951820. En: Historia, 44 (1), pp.51-89. PUCP Chile.

Cornejo SaAvedra, Raúl Estuardo (2009). El gran bandolero Froilán Alama. Vida, hechos, leyenda. RAISAPP, Perú.

Chust, Manuel (2010). América en las Cortes de Cádiz. Fundación MAPFRE, Madrid.

Chust, Manuel y Claudia Rosas (eds.) (2018). El Perú en Revolución. Independencia y guerra: un proce- so, 1780-1826. Universitat Jaume I; El Colegio de Michoacan, A.C., PUCP, Lima, Perú.

Dawe, John (1994). Enrique López Albújar y el estudio del bandolerismo peruano. En Debate Agrario, No 19 , CEPES, Lima, Perú.

Escobar Ohmstede, Antonio (2017). ¿Negociación o disputa entre «notables» de los pueblos? Las violencias colectivas en las Huastecas (México) en la década de los cuarenta del siglo xIx. En Historia: Debates e Tendencias, $\mathrm{N}^{\circ}$ 2, pp. 208-217. UPG en História, Universidade de Passo Fundo (PPGH/UPF), Brasil.

DAvio, Marisa (2012). ¿Vagos, traidores o desmotivados? Deserciones militares de sectores populares en Tucumán durante la primera mitad del siglo XIX. En: Dimensión Antropológica, Año 19, Vol. 54, enero/ Abril, México.

De La Serna, Juan Manuel (Dir.) (2010). De la libertad y la abolición. Africanos y afrodescencientes en Iberoamérica. Centro de Estudios Mexicanos y Centroamericanos, México. https://books.openedition.org/cemca/1606. Consultado en 12.01.2019.

Diez H., Alejandro (1998). Comunes y haciendas: procesos de comunalización en la sierra de Piura, siglos xIx-Xx. Cusco. Edic. CIPCA, CERA Bartolomé de las Casas. 2011. Gobierno comunal: entre la propiedad y el control territorial. El caso de la comunidad de Catacaos. SEPIA, Piura, Perú. 2012. Tensiones y transformaciones en comunidades campesinas. Cisepa, PUCP, Lima, Perú.

Di Meglio, Gabriel (2007). Viva el bajo pueblo!:la plebe urbana de Buenos Aires y la politica entre la revolución de mayo y el rosismo. Edic. Prometeo, Buenos Aires. 2013. Los «sans-culottes despiadados». el protagonismo político del bajo pueblo en la ciudad de buenos aires a partir de la revolución. En: Véronique Hébrard y Geneviève Verdo (eds.), Las independencias hispanoamericanas, Collection de la Casa de Velázquez (137), pp. 165-180, Madrid.

DAWE John y Lewis Taylor (1994). Enrique López Albújar y el estudio del bandolerismo peruano. En: Debate Agrario 19, pp. 135-141, CEPES, Lima, Perú.

Espinoza Claudio, César (2010). República, pueblos y municipios en Piura, siglo xIx. La experiencia política de Morropón y Chulucanas. Investigaciones Sociales, IIHS-UNMSM, No 24, pp. 223-244, Lima, Perú. 2013. Historia regional e historia de la tierra. Anotaciones sobre el valle de La Chira, San Lucas de Colan y Amotape, siglos XviII-xx. En: Arqueología y 
Sociedad N 26, pp. 339-368, UNMSM, Lima, Perú. 2016. Los Borbones, los hacendados y la justicia real en Piura a comienzos del siglo xIx La historia de vida de un zambo pardo y libre agobiado por sus amores, los jueces y la envidia de negros, zambos y mulatos. En: Investigaciones Sociales, $\mathrm{N}^{\circ} 36$, pp. 117-137, IIHS, UNMSM, Lima, Perú. 2016a. Negros esclavos y segregación espacial en la sierra de Piura: Siglos xviII y xIx. En: Arqueología y Sociedad, No 31, pp. 495-527, UNMSM, Lima, Peru. 2017. Joaquín de Helguero y el pensamiento económico borbónico en Piura a comienzos del siglo xix. En: Investigaciones Sociales, $\mathrm{N}^{\circ}$ 38, pp.107-126, IIHS, UNMSM, Lima, Perú. 2019. Señores de la tierra y negros colonos en Piura y Querecotillo. Apuntes sobre la lucha por la libertad y los derechos civiles en el proceso de nacimiento de la república entre 1825-1855. En: Investigaciones Sociales; Vol.22 N. ${ }^{\circ 40}$, pp.267-290; IIHS, Facultad de Ciencias Sociales, UNMSM, Lima, Perú. DOI: http:// dx.doi.org/10.15381/is.v22i40.15901 Consultado: 28.04.2019

Espinoza León, Carlos (2008). Froilán Alama, el bandolero. Casa Editora Piuranidad, Piura, Perú. 2011. Bandoleros. Sietevientos Editores, Sullana, Perú.

Espinoza Soriano, Waldemar (2014). Chachapoyas frente a la independencia política del Perú. Derrama Magisterial, Perú.

Ferreras, Norberto (2003). Bandoleiros, cangaceiros e matreiros: revisão da historiografia sobre o Banditismo Social na América Latina. En: Historia Vol. 22, No2, Sao Paulo. http://dx.doi.org/10.1590/S010190742003000200012. Consultado: 08.03.2019.

Figueroa Luna, Guillermo y Ninfa Idrogo Cubas (19941997). «No queremos amos». Lambayecanos en lucha por libertad e igualdad (afronorteńos, 1750-1850). En: Contrastes. Revista de Historia, N ${ }^{\circ}$ 9-10, pp. 97-127, Perú. 2014. Los indios, la plebe y los «godasos con fama de patriotas» Lambayeque 1820-1823. Instituto Francés de Estudios Andinos IFEA; Instituto de Estudios Peruanos IEP; Departamento de Historia, Universidad de California en Santa Bárbara; Centre de Recherches sur l'Amérique Espagnole Coloniale (CRAEC), Universidad de Paris III - SorbonneNouvelle; Ministerio de Educación MINEDU; Ministerio de Cultura; Congreso de la República.

Flores López, José Manuel (2018). La construcción política del bandido en el siglo XIX. En: Secuencia, N ${ }^{\circ} 102$, pp.100-126, Instituto Mora, México.
Fradkin, Raúl (2005). «Bandolerismo y politización de la población rural de Buenos Aires tras la crisis de la independencia (1815-1830)», en Nuevo Mundo Mundos Nuevos, EHESS, $\mathrm{N}^{\circ} 5$. http://nuevomundo.revues. org/309documento.html. Consulta 12.02.2019.

GinzburG, Carlo (1981). El queso y los gusanos. El cosmos, según un molinero del siglo XVI. Barcelona, Muchnik. 1993. El juez y el historiador. Consideraciones al margen del proceso Sofri. Edic. Vía Gráfica, S.A. Fuentelabrada, Madrid.

Ginzburg, Carlo; Enrico Castelnouvo y Carlo Poni (1991). A micro-história e outros ensaios. Edic. DIFEL, Lisboa.

Gutiérrez, Miguel (1991). La violencia del tiempo. Ediciones Milla Batres. Lima. 1998. Hombres de caminos. Editorial San Marcos, Perú.

Hernández G., Elizabeth (2007). El marqués de Salinas, Francisco Javier Fernández de Paredes, y su permanencia en la clase dirigente piurana a inicios de la República (1785-1839). En BIFEA, No36 (3, pp. 361-391, Lima, Perú. 2008. Lima. La elite piurana y la Independencia del Perú: la lucha por la continuidad en la naciente república: 1750-1824. Lima. UDEP, PUCP, IRA. 2011. Incertidumbre política y opción por la patria en el norte peruano: la independencia y los miembros del clero (1812-1824). En: Hispania Sacra, LXIII; Nº128, pp. 595-625, España. 2012. Crisis de autoridad en una región periférica: La vecindad piurana frente a la nueva patria (Perú, 1821-1824). En: revista Andina, N 52, pp. 113-128; CERA, Cusco, Perú.

Новзважм, Eric (1991). "Historiografía del bandolerismo». En: Sánchez, G. y Peñaranda, R. (comps.), Pasado $y$ presente de la violencia en Colombia, Bogotá, CEREC, pp. 61-71. 2001 (1969) Bandidos, Editor. Crítica, Barcelona. 2010 (1959]. Rebeldes primitivos: Estudio sobre las formas arcaicas de los movimientos sociales en los siglos XIX y Xx, Edit. Critica, Barcelona. 1978 (1973). Revolucionarios. Ensayos Contemporáneos. Editorial Ariel, Barcelona.

Hocquenghem, Anne Marie (1998). Para vencer la muerte. Piura y Tumbes: raíces en el bosque seco y en la Selva Alta - Horizontes en el Pacífico y en la Amazonía. París. CNRS-PICS-IFEA-INCAH, Lima, Perú.

Huertas Vallejos, Lorenzo (1996). «Patrones de asentamiento poblacional en Piura (1532-1850)». En: Instituto Francés de Estudios Andinos, $N^{\circ} 25$, pp. 91124, Lima, Perú. 
Hunefeldt, Christine (1992). Las Manuelos, vida cotidiana de una familia negra en la Lima del siglo XIX. Lima: IEP.

Jacobsen, Nils; Díez Hurtado, Alejandro (2003). De Sambambé a la Comuna de Chalaco: la multivocalidad de montoneros piuranos durante el tardío siglo XIX. Revista Andina, No 37, pp. 137-180.2002.

Jaramillo, Miguel (1995). Growth and underdevelopment: Trade and regional articulation in northern Peru, 1750-1930. University of California, San Diego.

Kapsoli, Wilfredo (2014). Esclavitud en el Perú. En Tradición, $\mathrm{N}^{\circ} 14$, pp. 63-70. Lima: Universidad Ricardo Palma.

Lavalle, Bernard (2018). En: Los cerros de La Libertad. Esclavos cimarrones en Trujillo Colonial. Editorial Universitaria Villarreal, Lima, Perú.

Levi, Giovanni (1995). Economía campesina y mercado de la tierra en el piamonte del Antiguo Régimen. En: Estudios Sociales, $N^{\circ}$ 9, pp. 91-107. Segundo Semestre. Universidad Nacional del Litoral, Argentina. 1989. Los usos de la biografía. En: Annales ESC, N6, noviembre; pp. 1325-1336. Traducción de Araceli Rodriguez Tomp. 2014. O trabalho do historiador: pesquisar, resumir, comunicar. EN: Revista Tempo. Vol.20, pp.1-20. http://www.scielo.br/pdf/tem/v20/ pt_1413-7704-tem-20-20143606.pdf. Consultado 25.10.2018. 1990. La herencia inmaterial. La historia de un exorcista piamontés del siglo XviI. Editorial NEREA, Madrid.

Lissandrello, Guido y Eduardo Sartelli (2018). Guerra popular prolongada y campesinado en el maoísmo argentino. El caso de Vanguardia Comunista (19651971). En: Cuaderno de Marte; Año 9, №14, pp. 105138; UBA, Argentina.

López Albujar, Enrique (1936). Caballeros del Delito. 2da. Edición, 1973. Editorial Juan Mejía Baca, Lima, Perú.

Löwy, Michael (2010). «Eric Hobsbawm, sociólogo del milenarismo campesino», En: Estudos Avançados, $\mathrm{N}^{\circ}$ 69, pp. 105-118, Instituto de Estudos Avançados da Universidade de São Paulo, Brasil.

Marchena, Juan y Nayibe Gutiérrez Montoya (2017). Formación académica, Ilustración, guerra y reforma: la naturaleza del mundo indígena andino a la luz de la oficialidad militar borbónica 1760-1790. En: El ocaso del antiguo régimen en los imperios ibéricos. Scarlett O’Phelan Godoy y Margarita Eva Rodríguez García (coordinadoras). CHAM. Universidades Nova de Lisboa y PUCP, Lima, Perú.

Martínez Peria, Juan Francisco y María de Lourdes GHidoli. (comp.) (2015). Estudios afrolatinoamericanos 2: Actas de las Cuartas Jornadas del GEALA. 1a ed. Ediciones del CCC Centro Cultural de la Cooperación Floreal Gorini, Ciudad Autónoma de Buenos Aires.

Navarro P. José y otros (1991). Vida y obra del obispo Baltasar Jaime Martínez Compañón. Piura, Universidad de Piura, Piura.

O’Phelan Godoy, Scarlett (comp.) (1999). El Perú en el siglo XviII. La Era borbónica. Instituto Riva Aguero, PUCP, Lima, Perú. 2011. El proceso de independencia y los sectores populares. En: Anuario de Estudios Americanos, Vol.68 (2), pp. 413-427, Escuela de Estudios Hispano-Americanos de Sevilla, España. 2009. Abascal y la reformulación del espacio del virreinato del Perú, 1806-1816. En: Política Internacional, Nº5-96, Lima, Perú. 2018. Recuerdos sobre Eric Hobsbawm. En Serie Conferencias: 17; pp. 7 - 14. Universidad del Pacífico, Lima.

Ossa Santa Cruz, Juan Luis (2016). 1814 en Chile: de la desobediencia a Lima a la ruptura con España. En: Anuario de Estudios Americanos, $\mathrm{N}^{\circ} 73$ (1); pp. 231260, Sevilla, España.

Peralta, Víctor (2008). El impacto de las Cortes de Cádiz en el Perú. Un balance historiográfico. En: Revista de Indias, $\mathrm{N}^{\circ}$ 242, pp. 67-96, Madrid. 2002. En defensa de la autoridad. Politica y cultura bajo el gobierno del virrey Abascal. Perú 1806-1816, CSIC, Madrid.

Piqueras, José Antonio (2016). La era de Hobsbawm en historia social. El Colegio de México, México

RAFART, Gabriel (2011). Violência rural e bandoleirismo na Patagônia. En: Topoi, $\mathrm{N}^{\circ}$ 22, pp. 118-136. UPG Historia Social, UFRJ, Brasil.

Ragas Rojas, José (2003). Afroperuanos: un acercamiento bibliográfico. En: Etnicidad y discriminación racial en la historia del Perú. Tomo II; pp. 190-226. Lima: Instituto Riva Agüero y Banco Mundial.

Ramírez Cueva, Roque (2013). Morropón: Lo negro y lo Mestizo. Ámbitos y Personajes en la Narrativa Regional y Nacional. En: https://creacionheroica1928.blogspot. com/2013/04/literatura.html Consultado 12.02.2019.

Renk, Arlena y Silvana Wincler (2017). Para uma biografía da pequeńa propiedade rural no oeste catarinense. En: Historia: Debates e Tendencias, № 2, pp. 307319. UPG en História, Universidade de Passo Fundo (PPGH/UPF), Brasil. 
Revesz, Bruno; Susana Aldana, Laura Hurtado y Jorge Requena (1997). Piura: región y sociedad. Derrotero bibliográfico para el desarrollo. Lima. CIPCA-CERA Bartolomé de las Casas. 1989. Agro y Campesinado. Ediciones CIPCA, Piura.

Romero, Fernando (1994). Safari africano y compraventa de esclavos para el Perú (1412-1818). Lima: IEP.

Sábato, Hilda (ed.) (1997). Ciudadania política y formación de las naciones. Perspectivas históricas de América Latina. México, FCE.

Salinas SÁnchez, Alejandro (2016). La Historia económica en el Seminario de Historia Rural Andina. En: revista ISHRA Vol.1, $\mathrm{N}^{\circ}$ 1, julio-diciembre; UNMSM; pp. 1-56, Lima, Perú.

Seminario, Miguel Arturo (1994). Municipalidad Provincial de Sullana, Maza Editores, 2da. Edición, Piura.

TARdieu, Jean-Pierre (2018). El negro Guillermo, Venezuela 1769-1771. Análisis de un discurso represivo del cimarronaje. Editorial Alfar. Sevilla. 2017. Resistencia de los negros en el virreinato de México (siglos XvIXVII). Iberoamericana - Vervuert, Madrid y Frankfurt. 2013. Resistencia de los negros en la Venezuela colonial: representaciones y planteamientos semiológicos. Vervuert, Madrid - Iberoamericana; Frankfurt am
Main. 2004. El decreto de Huancayo: la abolición de la esclavitud en el Perú, 3 de diciembre de 1854. Fondo Editorial del Congreso del Perú, Lima, Perú.

Tord Nicolini, Javier (1977). Del negro señorial al negro bandolero: cimarronaje y palenques en Lima. Siglo XVIII. Lima: PUCP.

VAnderwood, Paul J. (1986). Desorden y progreso, bandidos, policías y desarrollo mexicano. Siglo XXI Editores, México. 1984. El bandidaje en el siglo xIx: una forma de subsistir. En: Historia Mexicana, $\mathrm{N}^{\circ} 133$, pp. 41-73. El Colegio de México, México.

VAN Young, Eric (2012). Paul J. Vanderwood: una remembranza (1929-2011). En: Historia Mexicana, vol. LXI, núm. 4, abril-junio, 2012, pp. 1675-1682, El Colegio de México, México.

Vegas Seminario, Francisco (1960). Bajo el signo de la Mariscala: novela histórica. Tawantinsuyu, Lima, Perú. 1959. Cuando los mariscales combatían. Prólogo de Manuel Mujica Gallo; Tawantinsuyu, Lima. Montoneras (Novela). 1954. Juan Mejía Baca, Lima, Perú.

Vendrame, Inés (2018). Micro-história e história da imigraçáo: pensando o problema do equilíbrio e da complexidade. Tempo e Argumento, Florianópolis, v. 10, n. 25, p. $267-288$, jul./set., Brasil. 